\section{Kastamonu Eğitim Dergisi Kastamonu Education Journal}

Eylül 2019 Cilt:27 Sayı:5

kefdergi.kastamonu.edu.tr
Başvuru Tarihi/Received: 23.03.2018

Kabul Tarihi/Accepted: 03.12.2018

DOI: $10.24106 /$ kefdergi. 2869

\title{
Okul Müdürlerinin Ders Denetimi Görevlerinin Rehberlik Etkililiği Açısından Değerlendirilmesi ${ }^{1}$
}

\section{Evaluating School Principals' Classroom Supervision Tasks in Terms of Effective Guidance}

\section{Öz}

\author{
Ali SABANCI ${ }^{2}$, Nihat AKCAN ${ }^{3}$
}

Türk eğitim sisteminde Müdürün en önemli görev yetki ve sorumluluklarından birisi de personelin yetiştirilmesi ve geliştirilmesi için gerekli tedbirleri almak ve öğretmenlerin performanslarını artırmak amacıyla her öğretim yılında en az bir defa dersini izlemek ve rehberlikte bulunmaktır. Bu çalışmada Okul müdürleri tarafindan gerçekleştirilen ders denetimi etkinliklerinin rehberlik etkililiği açısından incelenmesi amaçlanmıştı. Araştrrma nitel araştırma desenindedir. Araştırma durum çalışmalarından bütüncül çoklu durum desenindedir. Çalışma Antalya ili Alanya ilçesinde bulunan ilkokullarda gerçekleştirilmiştir. Çalışma gurubunun belirlenmesinde maksimum çeşitlilik örneklemesi kullanılmıştr. Verilerin toplanması amacıyla yarı yapılandııılmış bir görüşme formu kullanılmıştr. Sonuç olarak, çalışma gurubu, iki özel ilkokul ile üç devlet ilkokulunda görev yapan toplam 5 müdür ve 5 öğretmenden oluşmuştur. Verileri elde etmek üzere yarı yapılandırılmış bir görüşme formu kullanılmıştır. Verilerin analizinde betimsel ve içerik analizi yöntemleri kullanılmıştı. Bulgulara göre okul müdürlerinin gözlem öncesi görüşme aşamasında, gözlem ve gözlem sonrası görüşmelerde kapsamlı bir denetim anlayışı yansıttıkları söylenebilir. Okul müdürlerinin başvurdukları düzey belirleyici değerlendirmenin yerine bireysel farklılıkları esas alan farklı değerlendirme yöntemlerine intiyaç olduğu anlaşılmaktadır. Ayrıca yapılan denetimlerde üzerinde durulan kapsamlı konuların niteliksel açıdan durumunu belirlemeye yönelik çalışmalara ihtiyaç vardır. Okul müdürleri, denetleme ve rehberlik konularında tüm süreçlerde intiyaç duyacakları bilgi ve becerileri kazandırmaya yönelik, süreklilik temelinde, teorik ve uygulamalı eğitimlerle desteklenmelidir. Denetim modeli olarak okul müdürünü merkeze alan bir yaklaşımda, modelin başarılı olabilmesi için okul müdürlerinin üstlendikleri görev ve sorumlulukların, öğretim ve program liderliği odaklı olarak yeniden yapılandırılması gerektiği söylenebilir.

Anahtar Kelimeler: Eğitim denetimi, okul denetimi, öğretmen denetimi, rehberlik

\section{Abstract}

In the Turkish education system, one of the most important tasks and responsibilities of the principal is take the necessary precautions for the training and development of the personnel and increase the performance of the teachers by monitoring and guiding classroom at least once every academic year. The purpose of this study was to examine classroom supervision activities conducted by school principals in practice in terms of effective guidance. In this study, qualitative research method has been used. The study was utilized using embedded multiple-case pattern. The study was conducted in primary schools in the district of Alanya of Antalya province. In selecting working group, maximum variation sampling was used. As a result, the working group consisted of 5 principals and 5 teachers working in two private and three state schools. A semi-structured interview form was used to obtain the data. Descriptive and content analysis methods were used in the analysis of the data. According to the data obtained, school principals have a comprehensive approach to classroom supervision for pre-observation, observation and after observation processes. There is a need for a different way of evaluating the supervision process because they still adopt the "evaluating with standards" approach. Moreover there is a need to determine the quality of the supervised topics found in this study. School principals should also be supported by theory and implementations about supervision in order to develop their skills and information. In order to be successful in principal based supervision model, the process should be re-organized constructing the position of the principal as instruction and programme leader.

Keywords:Educational supervision, guidance, school supervision, teacher supervision. 


\section{Extended Abstract}

Purpose:Education is an instrument which is effective in shaping the ages both by being a vital instrument in for an individual by means of self-development determined by personal abilities and interests, and being a unique way of providing cultural, social, political and economic survival, development and re-production processes of a society via information and abilities taught to individuals. Consequently, education can be referred as the unique way of providing welfare for both, individual and society. It is wise to think that in supervising and evaluating the whole education system, the whole members and institutions in the society play important roles and assume responsibilities directly or indirectly.

By the law for national education (Law number 1739) and the law for organizing and defining the duties of body of national education organization (Law number 652) the responsibility for evaluating and supervising all kinds of educational services on behalf of the Turkish Republic by Ministry of National Education. Based on these laws, in all levels and kinds of formal and lifelong learning education institutions and districts and provincial directorates of education, the inspectors were given the responsibilities of guidance, on-the-job training, supervision, evaluation, searching and investigating.

In Turkish education system, again based on the laws, principals are considered as one of the major sources to assess and supervise their schools for pre-primary, primary and secondary education levels. One of the most important task and responsibilities of the principal is to take the necessary precautions for the training and development of the personnel and increase the performance of the teachers by monitoring and guiding the lesson at least once every academic year. The purpose of this study was to examine lesson supervision activities conducted by school principals in practice in terms of effective guidance. This becomes reflection for different supervision models of the National Ministry Education.

Method: This research was designed in embedded multiple-case pattern which is a qualitative method. The research was conducted in Alanya, which is a district of Antalya province. Maximum variation sampling technique was used in selecting the working group. As a result, two private and three state primary schools were determined first and in the second stage, principals of the schools and five teachers working in these schools were chosen to constitute the working group. The data were gathered using a semi structured question form. In the process of collecting data, the interviewers were first informed about the interview and asked for approval and later, the interviews were conducted face to face. In order to provide validity, the data were tape-recorded and notes were taken by the two researchers. In the next step the recorded data were transcribed into text. The data were analysed by both descriptive and content analysis techniques.

Results and Conclusion: According to the results both state school principals and private school principals stated that they informed the teachers about the classroom visit for observation a short time ago and realized an interview. It was found that school principals discussed the subject of the lesson, materials and learning targets, measuring and evaluation activities with the teachers before observation.

About the observation dimension both state school principals and private school principals stated that they considered and assessed physical state of the classrooms, teaching techniques and methods, classroom rules, contents, the way the teachers process the lessons, transitions between the activities and integrating the learning topics, hygiene and self-care, differences among the students, emotions,

In the dimension of lesson observation both private and public schools' principals examine and assess physical condition, teaching methods and technologies, classroom rules, program content, course processing, use of course tools and materials, hygiene and personal care, individual differences, feelings, motivation, student-centred teaching practices, time management, effective communication process, encourage research and creativity by giving, reviewing and evaluating the activities.

In the post-observation interview dimension, it is understood that school principals have made planning with the teachers at the appropriate time, reviewing of the plans made at the beginning of the academic year, emphasizing the strengths and weaknesses related to course practices, reviewing methods, techniques, used activities and materials, evaluating different applications, discussing different applications towards eliminating deficiencies, making evaluation on the basis of creative-good examples.

At the end of the supervision of teachers and principals, mainly related to the views of the performance evaluation method, standard evaluation form and content has been created. Relatively, principals reflected the tendency to develop situational assessment criteria based on individual differences and the specific aspects of the course.

According to findings principals put their effort to gain proficiency through consultation from supervisors and colleagues and by using their own personal professional experience and the information provided in the regulation. Gaining of proficiency of supervision and guidance through education are expressed only by private school administrators.

Generally, it can be said that school principals are among the most important candidates because they have the appropriate groundwork and position to meet the need of supervision and guidance. Findings imply that the initiatives in order to improve this process towards a more positive process and results should be shared by all parties. 


\section{Giriş}

Türk eğitim sisteminde Müdürün en önemli görev yetki ve sorumluluklarından birisi de personelin yetiştirilmesi ve geliştirilmesi için gerekli tedbirleri almak ve öğretmenlerin performanslarını artırmak amacıyla her öğretim yılında en az bir defa dersini izlemek ve rehberlikte bulunmaktı. Bu çalışmada Milli Eğitim Bakanlığı'nın farklı denetim modeli arayışlarının bir yansıması olarak uygulamada bulunan okul müdürleri tarafindan gerçekleştirilen ders denetimi etkinliklerinin rehberlik etkililiği açısından incelenmesi amaçlanmıştır.

Eğitim sisteminin bütünde denetlenmesinde ve değerlendirilmesinde birey ve kurum bazında toplumun tamamının doğrudan veya dolaylı katkısından, rol ve sorumluluklarından söz edilebilir. Benzer şekilde eğitim sisteminin en temel alt sistemlerinden biri olan denetleme ve değerlendirme alt sisteminde yakın ve uzak çevrede bulunan etmenlerden öğrenci, öğretmenin kendisi, meslektaşları, okul yöneticileri, müfettişler, aile, akran grupları, ülkenin genel yönetimi ve dünyadaki gelişmeler önemli roller ve görevler üstlenirler (Bursalıoğlu, 2002; Çağlar, 2014).

Okul yönetimi eğitim yönetiminin bir alt alanı olarak amaçlar doğrultusunda insan ve madde kaynaklarının etkin ve verimli bir şekilde kullanılması; önceden belirlenen genel ve özel amaçların ilke ve kurallar doğrultusunda gerçekleştirilmesi olarak tanımlanabilir (Aydın, 2014; Okutan, 2016). Eğitim örgütlerinde verilen eğitim hizmetinin amacına ulaşıp ulaşmadığının belirlenmesi eğitim-öğretim etkinliklerinin geliştirilmesi ve daha iyi bir eğitim verilmesi açısından çok önemlidir (Oğuz, Yılmaz ve Taşdan, 2007). Eğitimin niteliğini artırmada denetim önemli bir görev üstlenmektedir (Uğurlu ve Usta, 2016). Eğitim denetmenlerinin eğitim sürecinin etkili bir şekilde düzenlenmesi, işletilmesi ve geliştirilmesinde önemli bir yeri vardır. Denetim sürecinin etkili işlemesi, denetmenlerin yeterliği, kişisel ve mesleki özelliklerine bağlıdır (Babaoğlan, 2016). Denetimin olmadığı bir örgütte başarının yakalanması, hedeflenen amaçlara ulaşılması, örgüt içinde huzurlu bir ortamın sağlanması, iş görenlerin olumlu örgütsel tutumlar sergilemesi mümkün görülmemektedir (Tok ve Demir, 2016).

Eğitim ve öğretim hizmetinin, devlet adına yürütülmesinden, gözetim ve denetiminden Milli Eğitim Bakanlığı sorumlu tutulmuş ve görevleri belirlenmiştir (Milli Eğitim Bakanlığı [MEB], 1973; MEB, 2011). Bu çerçevede 6764 sayılı kanunla Maarif müfettişlerinin görevleri "illerde il müdürüne bağlı olarak inceleme, araştırma rehberlik hizmetleri ile il müdürünün vereceği diğer görevleri yapar" şeklinde düzenlenmiştir. Görüldüğü gibi 6528 sayılı kanunla müfettişlere daha önce verilmiş olan işbaşında yetiştirme, denetim, değerlendirme ve soruşturma görevleri görev kapsamlarının dışına alınmıştı (Kayıkçı, 2016; MEB, 2011; 2014; MEB, 2016a). Sonuç olarak, iş başında yetiştirme ve denetim görevi okul müdürlerine bırakılmıştr. İlgili düzenlemelerde okul müdürü, Türk Millî Eğitiminin genel amaçlarına ve temel ilkelerine uygun olarak Anayasa, kanun, tüzük, yönetmelik, yönerge, genelge ve diğer ilgili mevzuat hükümleri doğrultusunda okulun amaçlarını gerçekleştirmek üzere tüm kaynakların etkili ve verimli kullanımından, ekip ruhu anlayışıyla yönetiminden ve temsilinden birinci derecede sorumlu eğitim ve öğretim lideri olarak tanımlanmaktadır. Bu çerçevede okul müdürünün en önemli görev, yetki ve sorumluluklarından birisinin de personelin yetiştirilmesi ve geliştirilmesi için gerekli tedbirleri almak ve öğretmenlerin performanslarını artırmak amacıyla her öğretim yııında en az bir defa dersini izlemek ve rehberlikte bulunmak olduğu belirtilmiştir (Devlet Memurları Kanunu, [DMK], 1965, md.10; MEB, 2013, Md.78,4d; MEB, 2014a, MEB, 2016b; MEB, 2016c; MEB, 2016d; MEB, 2016e).

Çağdaş eğitim denetimi okul müdürlerinin denetim etkinlikleri açısından yol gösterici niteliktedir. Çağdaş eğitim denetiminin ilkeleri şöyledir (Aydın, 2014): 1) Çağdaş eğitim denetimi amaçlı bir girişimdir ve sıra ve süreklilik içerir. 2) Çağdaş denetimde demokratik liderlik ve işbirliği esastr. 3) Denetimde hareket noktası var olan yapı ve koşullar ile ivedilik taşıyan sorunlar. 4) Denetimde öğrenme- öğretme ortamı bir bütün olarak ele alınır. 5) Çağdaş denetimde grup yaklaşımı, sorumluluğun paylaşıması, etkileşim, görüş birliği ve olumlu insan ilişkileri anlamlıdır ve etkin sonuçlar doğurur. 6) Denetim modelleştirilmiş bir süreç olarak değerlendirilmemelidir. 7) Denetimde bireysel farklılıklar esastir ve öğretmenlere kendilerini ifade etme ve kanıtlama olanağı tanınır. Bu çerçevede tüm denetim süreci sürekli bir araştırmaya dayalıdır. Denetimde, öğretmenin etkililiği konusunda doğru bilgilerin elde edilmesi, en önemli konulardan birisidir. İyi yetişmiş deneticiler, doğru bilgileri nasıl toplayacaklarını bilirler. Etkili veri toplama teknikleri, görülenlerin izlenmesi ve kaydedilmesinden daha öte bir anlam ifade etmektedir. Bu teknikler iyi planlanmış ve yapılandırılmış tekniklerdir (Aydın, i., 2016). Denetim kavramının algılanmasının onun ögelerinin bilinmesine bağlı olduğu belirtilmiştir (Başar, 2000). Bu çerçevede ilk olarak var olan durumun betimlenmesine ihtiyaç vardır (durum saptama). íkinci olarak karar için bilgi sağlama ve oluşturulan karar seçeneklerinin değerlendirilmesi gerekmektedir (değerlendirme). Üçüncü olarak eksikliklerin tamamlanması, fazlalıklarını çıkarılması, yanlışların, amaç ve planlardan sapmaların düzeltilmesi, daha iyi sonuçlar için önerilerin geliştirilmesi önem taşır (düzeltme ve geliştirme). 
Türkiye'de Maarif müfettişleri tarafindan gerçekleştirilen mevcut geleneksel denetim modeline ve işleyişine ilişkin alanyazınında yapılan çalışmalarda çeşitli sorunların vurgulandığı görülmektedir. Bu sorunların, geçmişten günümüze devam ettiği söylenebilir (Taymaz, 1995). Alan araştırmalarıyla belirlenen bulgulara göre geleneksel denetim uygulamalarında yapılan denetimlerin standart ölçüt ve süreçlere göre yapılması, kontrol odaklı şekilsel denetime ağırlık verilmesi, biçimsel denetime ağırlık verilmesi, müfettişlerin soruşturma ve rehberlik görevlerinin bir arada olması, müfettişlerin yetki ve sorumluluklarının fazla, görev alanlarının geniş ve iş yüklerinin fazla olması, denetim için ayrılan sürenin yetersiz olması, denetlenecek personel ve kurum sayısının fazlalığı, değerlendirmelerin objektif yapılmaması, programın yetiştirilememesi, denetmenlerin olumsuz tutumu şeklinde sorunlar bulunduğu anlaşılmaktadır (Aslanargun ve Tarku, 2014; Kayıkçı ve Şarlak, 2013; Memduhoğlu, 2012; Uçar, 2012).

Genel olarak bulguların mevcut denetim sisteminin işleyişine ilişkin memnuniyetsizlik duygu ve düşünceleri yansıttıkları söylenebilir. Bulgulara göre müfettişlerin de görevlerinin doğasından, çalışma koşullarından ve teftişte yaşanan sorunlardan kaynaklanan memnuniyetsizliklerinin oldukça fazla olduğu ve iş doyum düzeylerinin düşük olduğu belirlenmiştir (Kayıkçı, 2005; Kocabaş ve Yirci, 2011; Şahin, Çek ve Zeytin, 2011). Öğretmenlerin ise mevcut denetim sisteminin uygulamaları ile kendi gerçek kişiliklerinden uzaklaştkları, denetimlerin işlerine olan motivasyonlarına ve mesleki gelişimlerine katkılarının düşük düzeyde olduğu algısına sahip oldukları ifade edilmektedir (Özan ve Özdemir, 2010; Uçar, 2012). Bu konuda öğretmenler müfettişlerin okul içinde ve dışında sergilediği tutum ve davranışlarla öğretmenlere örnek olma, yasal ödevlerini yerine getirirken kanun ve yönetmeliklere göre hareket etme, dış görünüşüne dikkat etme, temiz ve güzel giyinme konularında ise yeterli özeni göstermedikleri görüşündedirler. Öğretmenler, müfettişlerin, strese neden oldukları, hata arayıcı bir görüntü verdikleri, alan bilgisinin yetersizliği, hataların başkalarının yanında söylenmesi, dönüt sağlamama, var olan koşulları dikkate almama, deneyimi aktaramama, düşük beklenti ifade etme, yasal gücü öne çıkarma gibi çok sayıda konuda motivasyonlarının olumsuz etkilendiğini ifade etmişlerdir (Akcan ve Polat, 2015; Erdem ve Eroğul, 2012). Benzer şekilde denetmenlerin rollerini yüksek düzeyde gerçekleştirdikleri, mesleki değerler ve kişisel gelişimi, öğretme ve öğrenme sürecine ilişkin yeterlikleri, okul, aile ve çevre ilişkileri, program geliştirme ve içerik bilgisi ile öğrenci rehberlik hizmetleri boyutlarında öğretmenlere rehberlik etme görevlerini gerçekleştirme konularında olumlu düşünceler taşımalarına karşılık öğretmenlerin aynı düşüncede olmamaları denetim uygulamalarının amaçlara uygunluk bakımından yeniden değerlendirilmesi ihtiyacını doğurmaktadır (Aküzüm ve Özmen, 2013; Aslanargun ve Tarku, 2014; Karakuş ve Yasan, 2013; Sabancı ve Şahin, 2007; Sağlam ve Demir, 2015).

Denetmenlere ilişkin metaforla çalışmalarında da çoğunlukla olumsuz kavramların kullanılması bütünde denetime ve denetmene ilişkin algıların olumsuz olduğunu ortaya koymaktadır. Bu konudaki çalışmalarda denetmenlerin bile kendileri hakkında yetiştirici, değerlendirici, gözlemci gibi olumlu kavramlar yanında cezalandırıcı, açık arayan, otoriter şeklinde olumsuz metaforlar kullanmaları mevcut durumun değerlendirilebilmesi bakımından önem taşımaktadır. Denetlenen kişilerin kendileri hakkında ezilen, hesap veren, yönetilen, endişeli, oyuncu, düzeltilen ve gözlenen şeklinde olumsuz içerikli kavramlar kullanmaları da geleneksel denetim uygulamalarının algılanan olumsuz niteliğini pekiştirmektedir (Demirtaş ve Kahveci, 2015). Yukarıda belirtilen sorunların bütünde etik sorunlara da yol açttğına ilişkin bulgular bulunmaktadır. Bir araştırmada örneğin müfettişlerin insan ilişkileri, rehberlik ve işbaşında yetiştirme boyutunda düşük öğretmen ve ders teftişi ile teftiş sonrası genel değerlendirme boyutlarında orta düzeyde etik dışı davranışlara sahip oldukları belirlenmiştir (Sabancı ve Yücel, 2014). Sonuç olarak yapılan araştırmalar, öğretmenlerin denetim konusundan MEB Bakanlık denetmenlerini çok az tercih ettiklerine ilişkin bulguları güçlendirmektedir (Altun, 2014)

Denetmenlerin rehberlik, mesleki yardım ve işbasında yetiştirme görevleri ile ancak teftiş, değerlendirme ve soruşturma görevlerinden arta kalan zamanda ilgilenebildiklerini göstermektedir. Türk Eğitim Sisteminde denetim anlayışının yeniden yapılandırılması gerektiği; son yıllarda yapılan ilköğretim müfettişi, eğitim müfettişi, eğitim denetmeni, eğitim denetçisi gibi isim ve makyaj düzenlemelerinin ötesinde felsefi ve yapısal düzenlemelere ihtiyaç olduğu belirtilmektedir (Aslanargun ve Göksoy, 2013). Öğretmenlerin denetim sürecinin amaca uygun olarak sürdürülmesinde denetmenler kadar yöneticilere de önemli görev ve sorumluluklar düşmektedir (Topçu, 2010). Bu noktada öğretmen görüşleri, beklentileri ve çekinceleri dikkate alınarak okul müdürleri merkezli olmak üzere denetim anlayışının yeniden yapılandırılması ve eğitim denetmenlerinin asıl görevlerinin ne olması gerektiği sorgulanmalıdır. Gerek mevcut denetim sisteminin güçlendirilmesini içeren, gerekse kliniksel denetim veya resmi olarak atanmış denetmenlerden başka öğretmenler dahil tüm eğitimcilerin denetim ve öğretimsel liderlik sürecinde yer alabilecekleri gibi alternatif denetim modelleri tarţşma konusu oluşturmaktadır (Altun, 2014; Cantürk ve Yılmaz, 2014; Memduhoğlu ve Taymur, 2016; Ceylan ve Ağaoğlu, 2010; Glikman, Gordon ve Ross-Gordon, 2014; Tanrı̈ğen, 1997).

Denetim, örgütsel etkililik için vazgeçilmez bir süreçtir. Bütün örgütlerde olduğu gibi eğitim örgütlerinde de denetim çok önemli bir süreçtir. Son yıllarda okul müdürlerinin yapacakları denetim etkinliklerine artan bir şekilde önem 
verilmektedir (Yılmaz, 2009). Okul müdürlerinin üstlendikleri rollerden birisi de okullarda etkili eğitimi gerçekleştirmeye yönelik olarak etkili öğretmen denetimini gerçekleştirebilmedir. Denetimden en üst düzeyde yarar sağlayabilmek için, okul müdürlerinin, formal bir denetimden çok, işbirliği, paylaşım, kolaylaştırıcılık gibi unsurların önem kazandığı, kişisel ve örgütsel gelişmeyi ön planda tutan ve beklentilere yanıt veren bir denetim yaklaşımı içinde olmaları gerekmektedir (Özmen ve Batmaz, 2004). Okul müdürlerinin denetim görevlerindeki yeterlikleri, öğretmenlerin örgütsel bağlııklarını etkileyebilir. Bu yüzden okul yöneticilerinin, denetim görevlerini objektif, adaletli bir şekilde yerine getirmeleri ile oluşan olumlu örgüt ortamının, öğretmenlerin örgütleriyle özdeşleşmesine, bağlılık düzeylerini artırmasına katkı sağlayacağı umulmaktadır (Yıldııım, 2013).

Okul müdürlerinin ders denetimi ile ilgili olarak farklı görüşler bulunmaktadır. Örneğin, bir araştırmada okul müdürünün denetim görevi üstlenmesini öğretmen ve müdürler olumlu bulurken müfettişler olumsuz olarak değerlendirmiştir (Tonbul, 2017). Başka bir çalışmada okul müdürlerine yönelik algının müfettişlere göre daha olumlu olduğu bulunmuş ve neden olarak da öğretmenlerin kendilerini okul müdürlerine daha yakın hissettikleri gösterilmiştir (Toytok ve Çılgın, 2015). Almanya'da yapılan bir çalışmada okul müdürlerinin çoğu müdürlerin denetimine olumlu görüş bildirirken bir bölümü de iş yükü ve benzeri gerekçelerle olumsuz görüş belirtmişlerdir (Bitan, Haep ve Steins, 2015). Okul müdürlerinin tek başına veya diğer paydaşlarla birlikte denetim yapmalarının uygun olacağını düşündüklerine ilişkin bulgular da vardır. Okul müdürlerinin öğretmeni ve öğrencileri daha iyi tanıma, öğretmenlerle daha iyi iletişim kurma, uzun süreli gözlem vb. tüm yönleriyle öğretmenin bir yıllık performansını değerlendirebilecek verilere sahip olma ve sorunlara vakıf olma bakımından avantajları olduğu düşünülmektedir (Altun, 2014; Demirtaş ve Akarsu, 2016; Tonbul, 2017). Bu konuda olumsuz görüşler de vardır. Sözgelimi maarif müfettişleri okul müdürlerinin denetim görevini yerine getirmede yetersiz olduklarını ve yeterli bilgiye sahip olmadıklarını ifade etmişlerdir (Altun, Şanlı ve Tan, 2015). Müdürlerin, denetim yetkisini baskı aracı olarak kullanabileceği ve bu durumun da öğretmenler arası bölünmelere, çatışma ve kamplaşmalara neden olabileceği; öğretmen ve idare arasında yaşanabilecek gerilimin eğitim-öğretim niteliğinin azalmasına neden olabileceği, yöneticinin denetleyeceği branşta yeterli olmaması, taraf tutma veya sürekli eleştirel bir tutum takınma olasılıkları, performanslarını kısa bir süre içerisinde değerlendirmenin kanaat oluşturmaya yeterli olmaması gibi olumsuz yönlerine dikkat çekmişlerdir (Demirtaş ve Akarsu, 2016; Yıldız, Akbaşlı ve Üredi, 2015a; 2015b; Tonbul, 2017).

Bu çalışmada, Milli Eğitim Bakanlığı'nın farklı denetim modeli arayışlarının bir yansıması olarak uygulamada bulunan okul müdürleri tarafindan gerçekleştirilen ders denetimi etkinliklerinin rehberlik etkililiği açısından incelenmesi amaçlanmıştır.

\section{Yöntem}

\section{Araştırmanın Modeli}

Bu araştrrmada nitel araştırma yöntemi kullanılmıştır. Araştırma durum çalışmalarından bütüncül çoklu durum desenindedir. Bu desende birden fazla kendi başına bütüncül olarak algılanabilecek durum söz konusudur. Her bir durum kendi içinde bütüncül olarak ele alınır ve daha sonra birbiriyle karşılaştırılır. Bu çalışmada da iki özel okul ve üç devlet okulu bütüncül çoklu durum oluşturmaktadır. Burada önemli olan araştırmacının her üç okulda da aynı şeylere bakıyor olmasıdır (Creswell, 2014; Patton, 1990; Rubin ve Rubin, 1995; Yıldırım ve Şimşek, 2008).

\section{Çalışma Gurubu}

Çalışma Antalya ili Alanya ilçesinde bulunan ilkokullarda gerçekleştirilmiştir. Çalışma gurubunun belirlenmesinde maksimum çeşitlilik örneklemesi kullanılmıştı (Creswell, 2014; Patton, 1990; Rubin ve Rubin, 1995; Yıldırım ve Şimşek, 2008). Bu amaçla Alanya ilçesinde merkezde bulunan iki özel ilkokul ile üç devlet ilkokulu seçilmiştir. Sonuç olarak çalışma gurubu 5 müdür ve 5 öğretmenden oluşmuştur.

\section{Veri toplama araçları}

Verileri elde etmek üzere yarı yapılandırılmış bir görüşme formu kullanılmıştr. Bütüncül çoklu durum deseninde araştırmacının tek bir problem durumundan yola çıkarak okullara standart bir araçla (görüşme formu) gitmesi önemlidir. Bu çerçevede görüşme formunun birinci bölümünde kişisel bilgilere; ikinci bölümünde ise denetim öncesi görüşme, görüşme ve denetim sonrası görüşme olmak üzere üç aşamayı içeren ders denetim süreci ile ilgili verileri elde etmek için ana ve sonda sorulara yer verilmiştir (Creswell, 2014; Patton, 1990; Rubin ve Rubin, 1995; Yıldırım ve Şimşek, 2008). 


\section{Veri Toplama Süreci ve Analiz}

Verilerin toplanması sürecinde katlımcılara uygun zaman ve yer planlaması yapılmıştır. Katlımcıların her biri ile yüz yüze görüşülmüş ve öncelikle süreç hakkında bilgilendirilerek sözlü onayları alınmıştr. Verilerin geçerliliğini ve güvenirliğini artırmak için görüşmelerde birden fazla görüşmeci bulunmuş, görüşmeler ses kayıt cihazı ile kayıt altına alınmış ve ihtiyaç duyulduğunda not tutma yöntemi kullanılmıştir. Görüşmeler yüz yüze gerçekleştirilmiştir. Görüşme verileri ses kaydı ile kayıt altına alınmış ve not tutma yöntemi ile desteklenmiştir. Verilerin analizinde gözlem öncesi, gözlem aşaması, gözlem sonrası görüşme, değerlendirme ve denetsel yeterlik kazanma yöntemleri olmak üzere belirlenmiş olan beş ana tema betimsel analiz yöntemi ana temaların alt temalarını oluşturma sürecinde ise içerik analizi yöntemi kullanılmıştır. Bu amaçla ana temalara göre toplanan verilerin önce kavramlaştıııması daha sonrada ortaya çıkan kavramlara göre mantıklı bir biçimde düzenlenmiş ve buna göre veriyi açıklayan temaların saptanmıştır (Creswell, 2014; Patton, 1990; Rubin ve Rubin, 1995; Yıldırım ve Şimşek, 2008).

\section{Bulgular}

Bu bölümde; 1) Okul müdürlerinin ve öğretmenlerin gözlem öncesi görüşme sürecinde; ders gözlemi sürecinde ve gözlem sonrası görüşme sürecinde okul müdürlerinin gerçekleştirdikleri denetsel etkinliklere ilişkin görüşlerine; 2) Okul müdürlerinin ve öğretmenlerin okul müdürlerinin öğretmenlerin ders performanslarını değerlendirme yöntemlerine ilişkin bulgulara ve son olarak 3) Okul müdürlerinin denetim yapma yeterliği kazanma yöntemlerine yer verilmiştir.

1. Okul müdürlerinin ve öğretmenlerin gözlem öncesi görüşme (tablo 1, tablo 2), gözlem aşaması (tablo 3 , tablo 4) ve gözlem sonrası görüşme (tablo 5, tablo 6) süreçlerine ilişkin görüşleri.

Tablo 1. Okul müdürlerinin görüşlerine göre gözlem öncesi görüşme sürecinde gerçekleştirdikleri denetsel etkinlikler.

\begin{tabular}{|c|c|c|c|c|c|}
\hline \multirow{2}{*}{ Temalar } & \multicolumn{3}{|c|}{ Devlet Okulu } & \multicolumn{2}{|c|}{ Özel Okul } \\
\hline & M1 & $\mathrm{M} 2$ & M5 & M3 & M4 \\
\hline $\begin{array}{l}\text { Eğitim Öğretim yılının başında, yıllık plan çalışmalarında ve öğretmenler kurulu } \\
\text { toplantılarında gündeme alma }\end{array}$ & * & $*$ & & $*$ & \\
\hline $\begin{array}{l}\text { Denetimin gerçekleştirileceği ders öncesi haber verme ve gözlem öncesi görüşme } \\
\text { yapma }\end{array}$ & $*$ & * & $*$ & * & $*$ \\
\hline $\begin{array}{l}\text { Gözlem öncesinde dersin konusu, kullanılacak yöntemler ve teknikler hakkında } \\
\text { değerlendirme yapma }\end{array}$ & $*$ & $*$ & & * & $*$ \\
\hline $\begin{array}{l}\text { Etkinlikler ve materyaller ile kazanım ölçme ve değerlendirme etkinlikleri hakkın- } \\
\text { da konuşma }\end{array}$ & $*$ & $*$ & & $*$ & $*$ \\
\hline
\end{tabular}

Tablo 1'de verilen temalarla ilgili olarak birinci tema konusunda M1: “Öğretmenler kurulunda arkadaşlar uygun zamanda önceden size bildirilmek üzere derslerinize girip dinleyeceğiz.", M3: "Yıllık plana uygunluğunu takip etmek için gerekli kontrollerimi yapıyorum. Kazanımları inceliyorum." ve M2: "Denetim yapacağımı senenin başında beliririm. Bir yönerge veririm ellerine." demişlerdir.

İkinci tema ile ilgili olarak M1: "Bu kapsamda öğretmenimize en az iki gün öncesinde söylüyoruz. Uygun olup olmayacağını soruyoruz.", M2: "Bir gün önceden hatrlatma yapılır.", M4:"Bir gün önceden ders denetimi yapacağım guruba bilgi veririm." ve M5: "Sözlü olarak 2 gün önce haber veririm." demişlerdir.

Üçüncü tema konusunda M3: "Genel Merkezden gelen kurumsal bütünlük açısından her konu için kullanılacak yöntem uygulanıp uygulanmadığı konuşulur.", M2: “Denetim öncesinde, evet görüşürüz.", ve M1: "Önceden öğretmenimiz isterse -sizin geleceğiniz saatte konumuz şudur, ...bununla ilgili önceden hazırlamış olduğum materyaller var... bunu akıllı tahtada veya projeksiyonda elektronik ortamda görüntüleyeceğim gibi... açıklayabilir." şeklinde ifadeler kullanmışlardır.

Dördüncü konusunda M3: "etkinlik ve materyal örneklerinin uygulanıp uygulanmadığı konuşulur.", M2: Çünkü burası ilkokul olduğu için özellikle birinci, ikinci, üçüncü sınıflarda kazanım değerlendirme formlarının hazırlanması gerektiğinden bahsederim ve hazırlatııı." ve M1: "Efendim daha sonra çocuklara soru cevapla anlatım yaptıracă̆ım. İsterse öğretmenimiz bunları açıklayabilir." demişlerdir. 
Tablo 2. Öğretmenlerin görüşlerine göre gözlem öncesi görüşme sürecinde okul müdürlerinin denetsel etkinlikler.

\begin{tabular}{|c|c|c|c|c|c|}
\hline \multirow{2}{*}{ Temalar } & \multicolumn{3}{|c|}{ Devlet Okulu } & \multicolumn{2}{|c|}{ Özel okul } \\
\hline & Ö1 & Ö2 & Ö4 & Ö3 & Ö5 \\
\hline 1. Denetimin gerçekleştirileceği ders öncesi haber verme ve gözlem öncesi görüşme yapma & $*$ & $*$ & $*$ & $*$ & $*$ \\
\hline 2. Sınıfin genel durumu, ders dışı etkinlikler ve veli boyutunda değerlendirme yapma & $*$ & $*$ & $*$ & $*$ & \\
\hline 3. Zümre kararları ve ders programı hakkında değerlendirme yapma & & & $*$ & & $*$ \\
\hline $\begin{array}{l}\text { 4. Ders programı, teknoloji kullanımı, sınıf yönetimi stratejileri, öğrenci istenmeyen davranış- } \\
\text { ları hakkında değerlendirme yapma }\end{array}$ & $*$ & & $*$ & $*$ & $*$ \\
\hline 5. Öğrenme güçlükleri ve bireysel algı farklılıkları hakkında değerlendirme yapma & $*$ & & $*$ & $*$ & $*$ \\
\hline 6. Dersi destekleyici çeşitli etkinliklerin değerlendirilmesi & $*$ & & & $*$ & $*$ \\
\hline
\end{tabular}

Tablo 2'de gözlem öncesi görüşme ile ilgili temalar verilmiştir. Birinci tema ile ilgili olarak Ö1: "Müdür Bey beni odasına çağırdı. Odasında dersi denetlemeye gelmek istediğini söyledi.", Ö2: "Önceden bana haber verdi. Sözlü olarak haber verdi. Dersinize gireceğim dedi.", Ö4: "Sözlü olarak haber verdi.", Ö5: “Ders içi denetimler olacağını söyledi.", ve Ö3: "Hafta içi ders saatinin uygunluk durumuna göre randevu alarak gelmek istedi." demişlerdir.

İkinci tema ile ilgili olarak Ö1: "Sınıfın durumunu sordu. Denetime geleceğini, öğrenciler hakkında bilgi talep edeceğini söyledi. Ben de hazır olduğumu öğrencilerin durumunun iyi olduğunu söyledim.", Ö4: "Sınıfın seviyesi hakkında bilgi verdim." ve Ö5: "Sınıf yönetimi, müfredat ve konu anlatımlarının düzeye uygunlu hakkında konuşmuştuk." demişlerdir.

Üçüncü tema ile ilgili olarak Ö4: "Zümrede alınan kararları okuduk.” ve Ö5:"Zümre tutanaklarını inceledi. Her hafta düzenli olarak hazırlanmasını söyledi." demişlerdir.

Dördüncü tema ile ilgili olarak Ö5: "Akıllı tahta ve diğer kaynaklarla ilgili konuşuldu.", Ö3:"Öğrencilerle birlikte yapılan etkinlikler ve çalışmalar anlatıldı ve paylaşılı." ve Ö4: "Sınıfımla ilgili yaptığım ve planladığım çalışmaları anlattım." şeklinde ifadeler kullanmışlardır.

Beşinci tema ile ilgili olarak Ö1:"Sınıfta geride kalan 1-2 öğrencim vardı. Konuşma problemi olan öğrencim var. Onunla ilgili bilgi verdim kendisine. Sonradan gelen öğrencim vardı. Gerideydi. Onunla ilgili yapmış olduğum ekstra çalışmaları anlattım." şeklinde ifade kullanmıştr.

Altnncı tema ile ilgili olarak Ö1: "Sosyal etkinliklerde öğrencilerle neler yaptığımızı velileri ziyaret ettiğimle ilgili, veli ziyaretlerinde bulunduğumu, öğrenci ve velilerle piknik tarzı organizasyon düzenlediğimizi söyledim. Konuştuk. Gayet memnun oldu. Güzel çalışmalar hocam, dedi.”, Ö3: "Planlama dahilinde ders dışı sosyal etkinlikler paylaşıldı.”

Ö5: “Kulüp çalışmalarında görev alacağım konuşuldu. Hayat vizyonum ve gelecek planlarım hakkında konuştuk.” ve Ö2: "Sosyal etkinliklere önem veriyor müdür bey sınıf içerisinde veya okulda arkadaşlara sosyal etkinlikler konusunda çocuklara destek vermenizi ve bu konularda çalışmamızı söyledi." demişlerdir.

Tablo 3. Okul müdürlerinin görüşlerine göre ders gözlemi sürecinde gerçekleştirdikleri denetsel etkinlikler

\begin{tabular}{|c|c|c|c|c|c|}
\hline \multirow{2}{*}{ Temalar } & \multicolumn{3}{|c|}{ Devlet Okulu } & \multicolumn{2}{|c|}{ Özel Okul } \\
\hline & M1 & $\mathrm{M} 2$ & M5 & M3 & M4 \\
\hline 1. Sınıfin fiziki durumun öğrenmeyi desteklemesi & $*$ & $*$ & & * & \\
\hline 2. Öğretim yöntemlerinin ve teknolojinin etkin kullanımı & * & $*$ & * & * & * \\
\hline 3. Etkin dinleme, ses tonu, beden dili kullanımı, jest ve mimikler & $*$ & $*$ & * & $*$ & \\
\hline $\begin{array}{l}\text { 4. Duyguları önemseme, farklı fikirleri değerlendirme, yaratıcılığı özendirme, saygı, sevgi ve nezaket } \\
\text { kurallarına özen }\end{array}$ & * & * & * & * & $*$ \\
\hline 5. Bireysel farklılıklar, öğrenme hızı ve algısal farklılıkları dikkate alma & * & & & * & * \\
\hline 6. Okul ve sınıf kurallarının uygulanması & $*$ & * & $*$ & & \\
\hline 7. Öğretim konularını ilişkilendirme, konular arası geçişin sağlanması & & $*$ & * & * & \\
\hline 8. Öğrenci merkezli öğretim uygulamalarının değerlendirilmesi & * & * & & * & \\
\hline 9. Dikkati sağlama, kendini ifade etme firsatı ve uygulama olanakları sağlanması & & * & & * & \\
\hline 10. Zamanın etkili ve verimli kullanılması & * & $*$ & & * & * \\
\hline 11. Ödev uygulamalarının bireysel farklılıkları esas alan araştırma ve yaratıcılığı özendirmesi & * & * & * & * & $*$ \\
\hline 12. Ders araç-gereçlerinin, ders etkinliklerinin ve materyallerin etkili kullanılması & * & & & * & \\
\hline 13. Kişisel bakım ve kişisel gelişim durumu & * & * & * & $*$ & $*$ \\
\hline 14. Öğrenci başarısının değerlendirilmesi için süreç değerlendirmesine ilişkin yapılan uygulamalar & * & $*$ & & & $*$ \\
\hline
\end{tabular}


Tablo 3'te verilen temalarla ilgili olarak birinci tema ile ilgili olarak M1: "Sınıf kitaplığı var mı? Yok mu? Ona bakarız. Kitaplıktan aktif olarak faydalanılıyor mu?", M2: “Hemen panolara gözüm ilişir. Gerçekten panolar güncel mi? Öğrenciler mi yapt bunu? Acaba yönlendirme ile mi yapıldı?" ve M3: "Ayrıca öğrencilerin kişisel eşyaları düzenli mi onu da kontrol ederim." şeklinde ifadeler kullanmışlardır.

İkinci tema ile ilgili olarak M1: "Teknoloji ve eğitim buluştunuz mu?", M3: "Teknik araçların kullanılması gözlemlenir.", M4: "Teknoloji, araç-gereç kullanımı, öğrenciyi merkeze alma durumunu gözlemlerim.", ve M5: "Teknoloji yeterince kullanılmalıdır." demişlerdir.

Üçüncü tema ile ilgili olarak M1: “Beden dilini, konusu önemli. İlkokul öğretmenleri...benim okulumdaki arkadaşlarım bu konuda oldukça dikkatli ve riayet ediyorlar.", M3: "Ses tonu iyi kullanıyor, jest ve mimikleriyle renkli bir anlatım gerçekleştiriyor.", M5: "Yine son sınıf gözlemimde arkadaşımın jest ve mimiklerini çok güzel kullandığını gördüm." ve M2: "Girmiş olduğum sınıflar için dinlendiğini ve dinlenilmediğini de söyleyebilirim etkin bir şekilde. Çünkü etkin bir şekilde dinlemek bir taraftan yazı yazarak dinlemek değildir. Her İşi bırakıp, çocuğun gözlerine bakıp, evet şimdi söyle ne istiyordun?" şeklinde ifadeler kullanmışlardır.

Dördüncü tema ile ilgili olarak M4: "Genellikle ben leb demeden leblebiyi anlarım güveni ile öğrenciyi anlamadığına şahit olabilirsiniz.", M3: "Bu açıdan da bakabiliriz ama ..." diyerek öğrenciyi rencide etmiyor. Soruyu anlaşılır bir şekilde istenen cevaba odaklayarak tekrar yöneltiyor... Öğrencileri saygıyla dinliyor." ve M5: “Öğretmenlerimizin farklı fikirlere açık olduğunu gözlemliyorum... Öğrencilere, isimleri ile hitap ediyorlar." demişlerdir.

Beşinci tema ile ilgili olarak M3: "Evet, öğretmen öğrencilerin kendini ifade edebilmesi için yeterince firsat tanıyor, sık sık beyin firtınası yaptırarak düşünme becerisi kazandırıyor.", M4: "Genellikle birkaç parlamış öğrenci daha şanslı.", M2: "Onu da gözlemliyorum. Mesleğini seven mesleğine aşık öğretmenlere bakıyorum, mesela bir sosyal etkinlikte ya da derste sorularını sorarken sınıfin geneline değil, bireysel olarak yönelttiğini gördüm." ve M3: "Öğrencilerin de soru sormasına firsat vermesi, öğrencilere geri bildirimler vermesi." şeklinde ifadeler kullanmışlardır.

Altıncı tema ile ilgili olarak M1: "Kuralları birlikte belirledik en önemlisi de bu. Sene başında belirlendi. Sıkıntıya düşüğü zaman baş gösteren bir problem varsa çözümü konusunda sınıfta ortak bir çözüm yolu aramak gerekir.", M2: "Biz onu okul olarak yapttk. Önce öğretmenler kurulunda okul kurallarını belirledik." Daha sonra sınıflarda bu tartı̧ıldı. Illaveler oldu. Çıkarmalar oldu.", M1: "Kuralları panoya asmak, yani yazılı hale getirmektir En etkili yöntemlerden birisi budur." ve M5: "Bazı sınıflarda okul ve sınıf kurallarının panoya asıımış olduğunu gözlemliyorum." demişlerdir.

Yedinci tema ile ilgili olarak M2: "Bunu çok güzel yapan arkadaşlarımız var. Öğretmen konuya başlamadan önce bir beyin firtınası yapıp daha önce öğrendikleriyle ilgili hatılatmada bulunduktan sonra derse geçtiği zaman daha etkili oluyor.", M3: "iş̧lenen konuyu geçmiş derslerle ilişkilendirip, hatılatmalar yapıyor. Zaman zaman diğer derslerde öğrendikleriyle de ilişkilendirme yaparak disiplinler arası ilişkilendirme yapıyor." ve M5: "işslenen konular genelde öncekilerle ilişkilendiriliyor." şeklinde ifadeler kullanmışlardır.

Sekizinci tema ile ilgili olarak M1: “Girdiğimiz bir sınıfta öğretmenimiz öğrencilerin aktif olduğu bir öğrenme ortamı oluşturmuştu. Öğrenciler rahatlıkla soru soran, fikirlerini açıkça söyleyebilen söz isteyerek konuşan bir öğrenme ortamı vardı sınıfta." demişlerdir.

Dokuzuncu tema ile ilgili olarak M3: "Son sınıf gözlemimde öğretmen hem işitsel hem görsel hem de yaparak ve yaşayarak öğrenmeye yönelik farklı etkinlikler uyguladı, sınıfinda olan yabancı öğrencilere onların anlayacağı şekilde birebir aktarımlarda bulundu... Öğretmenin öğrencilere de soru yöneltmesi, yeterli bekleme süresi vermesi, öğrencilerden aldığı cevaplarla asıl cevapları bütünleme..." ve M4: "Öğrencilerin hazır oluşu, öğretmenin bir uyarıcı ile dikkatleri toplaması, zamanı kullanmasını gözlemlerim." şeklinde ifadeler kullanmışlardır.

Onuncu tema ile ilgili olarak M5: "Son ders denetimimde öğretmenim zamanı iyi kullanmışt. Genelde ders içinde zamanı verimli kullanma gayreti içerisindedir öğretmenler.", M4: "Öğrencilerin hazır oluşu, öğretmenin bir uyarıcı ile dikkatleri toplamasını, zamanı kullanmasını gözlemlerim.", M3: "Zamanı etkin kullanılmaktadır. Öğrencilerin dikkat sürelerini gözetmiştir.", M2: "Öğretmenim Okula gelirken saat 8.30 da toplanma zili çaldıysa 8.30 da değil de 8.30 dan daha önce okula gelmelidir." ve M1: "Zaman kullanma çok hassas bir konu ve öğretmenlerimizin en çok dikkat ettiği konulardan birisidir." demişlerdir.

On birinci tema ile ilgili olarak M3: "Iş̧lenen konuyla ilgili ev uygulaması vermeli... Daha çok araşttrmaya yönelik olmalı.", M5: "Öğrencilere fotokopi verip vermediğine bakarım. İşlenen konu ile ilgili paralellik sağlıyor mu incelerim.", M1: "Ödev konusunda, zaman zaman zümre toplantıları yapıyoruz biz Burada ödev gündeme geliyor. Çocukları bıktırıcı 
usandırıcı ödevlerin verilmemesi konuşuluyor.", M4: "Ödevlerin yorucu olmayan, veliye yük getirmeyen, ekonomik ve zaman anlamında külfet getirmeyen şekilde olmasına dikkat ederim.", ve M2: "Çocuğu daha çok çocuğu araştırmaya sevk edecek bilmediklerini öğrenmeye sevk edecek ödevler verilmesi gerektiğine inanıyorum." şeklinde ifadeler kullanmışlardır.

On ikinci tema ile ilgili olarak M4: "Genellikle Yörük kültürü gereği göç yolda düzelir örneği, gerekli araç-gerecin ders esnasında getirttirildiğine şahit olabilirsiniz." ve M1: "Şöyle düşünelim okulumuzda öğretmenimiz bir Mikroskobu götürdü sınıfina öğrencilerde beraber çalışıyor. Yani sadece düzeni kurup da gelin bakayım sırayla buradan bakın ve sadece oradaki görüntüyü görün anlamında değil çocuklara onun nasıl çalıştı̆ııı öğretmenlerimiz bilgi aktarımı yapıyor." demişlerdir.

On üçüncü tema ile ilgili olarak M1: "Bu konuda kamu görevlileri içerisinde kişisel bakımına en çok riayet eden öğretmenlerdir Kendi mesleğim olduğu için değil, kendi meslek grubunu kayırma kadına değil. Çünkü öğretmenler dinamik görevi yerine getiren insanlardır", M2: "Yani büyük bir çoğunluğu kişisel bakımlarını gerçekleştiriyorlar.", M3: "Öğretmenler özenli ve temizdirler.", M4: "Dikkatli olanlar tabi ki var ama azımsanmayacak kadar dikkatsiz davrananları hep görürsünüz." ve M5: "Öğretmenlerimiz kılık kıyafetle genelde öğrencilere rol modeldir." şeklinde ifadeler kullanmışlardır." şeklinde ifadeler kullanmışlardır.

On dördüncü tema ile ilgili olarak M1: "Bilgi beceri aktarımları yapılıyor. Bilgi aktarımının kalıcılığı için davranışın kalıcılığı yönünde sürekli çalışmalar yapılıyor." ve M4: "Yanlış ya da a ben senden beklemezdim tepkisi oluşur. Olması gereken yanlış cevap da olsa neden, niçin, sorularını devreye sokup sonra konuşarak düzeltme yapmak gerekir." demişlerdir.

\section{Tablo 4. Öğretmenlerin görüşlerine göre ders gözlemi sürecinde okul müdürlerinin denetsel etkinlikleri.}

\begin{tabular}{|c|c|c|c|c|c|}
\hline \multirow{2}{*}{ Temalar } & \multicolumn{3}{|c|}{ Devlet Okulu } & \multicolumn{2}{|c|}{ Özel Okul } \\
\hline & Ö1 & Ö2 & Ö4 & Ö3 & Ö 5 \\
\hline Sınıfin fiziki koşullarının değerlendirilmesi & * & * & $*$ & $*$ & $*$ \\
\hline Zamanı etkili ve verimli kullanma & & $*$ & $*$ & & $*$ \\
\hline Etkinlik ve materyal destekli öğrenci merkezli program uygulama & $*$ & $*$ & & & $*$ \\
\hline Öğrencilerin bireysel farklılıklarına dayalı öğrenme ihtiyaçlarını karşılama & $*$ & $*$ & & $*$ & \\
\hline Amaca uygun etkinlik ve materyal tasarlama & $*$ & * & & & $*$ \\
\hline Amaca uygun yöntem ve teknik kullanımı & & * & * & $*$ & $*$ \\
\hline Ödev uygulamalarının zamanlama ve kontrolü & & $*$ & & & $*$ \\
\hline Öğretmenin alan uzmanlığı ve uygulama yeterliği & & $*$ & & $*$ & $*$ \\
\hline
\end{tabular}

Tablo 4'te verilen birinci tema ile ilgili olarak Ö1: "Yani daha önce dolapların ve sıraların kullanımı ile ilgili bir görüşmemiz oldu. Yani öğrencilerin kullanırken daha dikkat etmeleri, bu panoların yıllarca kullanılacağı, daha dikkatli olunması konusunda görüşmüştük.", Ö2: "Mesela projeksiyonumuz var karartmayı gayet güzel yapabiliyoruz. Sınıfta her türlü materyalimiz olduğu için ortam uygun zaten.", Ö3: "Sınıflarımız öğrenme ortamına uygun (ışık-ısı) ve çok iyi bir şekilde dizayn edilmiştir... Ders araç-gereç bakım ve kullanımı hakkında bilgi paylaşımında bulundu.", Ö4: "Ders araç gereçlerimde eksiğimin olup olmadığını sordu." ve Ö5: "Ders araç ve gereçlerin özenli bir şekilde kullanılması ve amaca uygun olarak faydalanılması gerektiğini söyledi... Sınıf panolarında kısa konu özetlerinin olmasını söyledi. Çocukların faydalanabileceği haberlerin panoda olması önerisinde bulundu." demişlerdir.

İkinci tema ile ilgili olarak Ö2: "Evet müdür bey onayladı. Gayet güzel olduğunu ifade etti kendisi. Zamanı verimli kullandığımı söyledi.", Ö4: "Zamanı etkin kullandığımı söyledi." ve Ö5: "Öğrencinin öğrenmişlik düzeylerine göre zamanı verimli kullandığım konusunda müdür beyden olumlu ifadeler aldım." şeklinde ifade kullanmışlardır.

Üçüncü tema ile ilgili olarak Ö2: "Ders planında öğrenci merkezli çalışıyorum zaten. Tabii gerektiği durumlarda öğretmen işin içerisine giriyor. Öğrenci merkezliyiz zaten.", Ö1: "Evet daha çok klavuz kitabı kullandığımı söyledim. Klavuz kitap haricinde hazırladığım ve internetten indirdiğim seviyelerine uygun çalışmaları kullandığımı söyledim. Müdür bey de uygun olduğunu söyledi.", Ö5: "Evet konuşuldu. Kaynak ve materyaller zümrede belirlendikten sonra müdür beyin onayı ile işleme konar." ve Ö5: "Öğrenci merkezli ders planı yapmamız gerektiğini söyledi. Öğrencinin aktif rol alması konularında konuşuldu." Şeklinde ifadeler kullanışlardır. 
Dördüncü tema ile ilgili olarak Ö1: "Sınıfımıza sonradan katılan ve geride kalan öğrencilerle ilgili yaptiğım çalışmada bireysel farklılıkları dikkate aldığımı belirtmiştim. Hocam çalışmaları yapalım dedi.", Ö3: "Bireysel farklııklar her zaman göz önünde bulunduruluyor. Öneriler ve alınan kararları uygularım ve Ö2: "Bireysel farklılıları mutlaka göz önünde bulunduruyorum zaten. Her öğrencinin zekâ düzeyine göre hareket ediyoruz zaten." demişlerdir.

Beşinci tema ile ilgili olarak Ö1: "Yani uygun çalışmalar olduğunu söyledi sadece. Daha çok sınıf öğretmeninin yürütmesi gereken çalışmalardı bunlar.", Ö2: "Müdür Bey güzel olduğunu ifade etti. Memnun kaldığını söyledi." ve Ö5: "Konuyu anlatthktan sonra, çalışmalarımızın amaca uygun olduğunu belirtti." demişlerdir.

Altıncı tema ile ilgili olarak Ö3: "Müdürümüz öğretmenin aldığı kararları ve uyguladığı metot-teknikleri desteklemiştir.", Ö4: "Yöntem ve teknikleri kullandığımı belirtti.", Ö5: "Uyguladığım yöntem ve tekniklerin öğrenci merkezli olduğunu söyledi. Takdir ettiğini söyledi.”, ve Ö2: "Müdür beyin sürekli bu konuda yönlendirmeleri var. O şekilde Biz de hareket ediyoruz." şeklinde ifadeler kullanmışlardır." demişlerdir.

Yedinci tema ile ilgili olarak Ö5: "Verilen ödevlerin mutlaka zamanında kontrol edilmesi hakkında...", Ö1: "Hayır o konuda bir görüşmemiz olmadı.", Ö2: "Bu konuda görüşme yapmadık. Kendimin uyguladığı yöntemler var. Çocuklara ödevi indirme yapıyorum. Biz ödevi sınıfta halletmeye çalışıyoruz. Eve de göndermiyorum." demişlerdir.

Sekizinci tema ile ilgili olarak Ö2: "Bu konuda müdürün düşüncesi olumludur. Gayet güzel.” Ö3: "Olumlu ve destekleyici." ve Ö5: "Kendi branşım düzeyinde yeterli beceriye sahip olduğumu belirtti." demişlerdir.

Tablo 5. Okul müdürlerinin görüşlerine göre gözlem sonrası görüşme sürecinde gerçekleştirdikleri denetsel etkinlikler.

\begin{tabular}{|c|c|c|c|c|c|}
\hline \multirow[t]{2}{*}{ Temalar } & \multicolumn{3}{|c|}{ Devlet Okulu } & \multicolumn{2}{|c|}{ Özel Okul } \\
\hline & M1 & M2 & M5 & M3 & M4 \\
\hline Gözlem sonrası görüşme için uygun zamanın planlanması & $*$ & $*$ & & & \\
\hline Eğitim öğretim yılı başında yapılan planlamaların gözden geçirilmesi & * & $*$ & & & \\
\hline Ders uygulamalarında ilişkin olumlu yanların vurgulanması & * & * & & * & $*$ \\
\hline Ders uygulamalarına ilişkin zayıf yanların vurgulanması ve çözüm önerilerinin değerlendirilmesi & * & * & & * & * \\
\hline $\begin{array}{l}\text { Öğretim programı, derste uygulanan yöntemlerin ve tekniklerin, kullanılan etkinliklerin ve materyal- } \\
\text { lerin gözden geçirilmesi }\end{array}$ & * & * & * & & \\
\hline $\begin{array}{l}\text { Gözlem aşamasında kullanılan yöntem ve uygulamalarda not alınan farklı uygulamaların değerlendi- } \\
\text { rilmesi }\end{array}$ & * & * & & * & \\
\hline $\begin{array}{l}\text { Değerlendirme aşamasında ihtiyaç duyulan eksikliklerin giderilmesine yönelik farklı uygulamaların } \\
\text { tartışılması }\end{array}$ & & * & & & $*$ \\
\hline Değerlendirme aşamasında diğer meslektaşlarla paylaşılabilecek yaratıcı-iyi örneklerin konuşulması & & * & & $*$ & $*$ \\
\hline
\end{tabular}

Tablo 5'te verilen birinci tema ile ilgili olarak M1: “Dersin durumuna göre öğrencilerimizin tamamı ya da çoğunluğu teneffüse çıkmış, dışarıya gitmişse sınıfta, o an belirleyeceğimiz müdür odasında veya okulun bahçesinde uygun bir alanda rahat olabileceğimiz, öğretmenimize samimi iletişim kurabileceğimiz bir yerde genel bir değerlendirme yaparız." ve M2: "Özellikle denetimi bitirdikten sonra, ayrıca bir ders saati ayırarak, öğretmenle dersten sonra olabilir, öğle arası olabilir oturur sohbet ederiz. Eğitim öğretmen yapmış olduğum farklı uygulamaları o esnada anlatır. Tekrar sınıfa girer yerinde görürüm." demişlerdir.

İkinci tema ile ilgili olarak M1: "Bu konuda sürekli bilgi sahibiyiz Çünkü sene başında öğretmenler kurulunda hangi sosyal faaliyetler hangi öğretmenimizin sorumlu olduğu, bunlar bellidir baştan." ve M2: "Sene başında öğretmenler kurulu ve zümrede hepsini tekrarlıyorum ve önemsiyorum. Burada zaten karar veririz. Hangi etkinlikleri yapacağımızı en ince detayına kadar çıkarııı. Bilgi yarışması, satranç turnuvası, futbol turnuvası, sene başında zamanı ve mekanı belirleriz. Zamanı gelince uygularız." demişlerdir.

Üçüncü tema ile ilgili olarak M1: "Öğretmenimize denetimin sonunda sınıfta şunları şunları olumlu bulduğumu, şu konularda da kendi görüşüm olarak şu şekilde yapılabileceğini, yapılmasının daha iyi olabileceğini düşünüyorum derim.", M2: "Olumlu yönlerden başlarım. Neleri güzel yaptıysa öncelikle onları söylerim.", M2: "Öncelikle öğretmeni motive edecek şeylerden başlarım. Olumlu yönlerden başlarım." ve M3: "Denetim süreci doğrultusunda birebir öğretmenle güçlü yönleri; geliştirmesi gereken yönleri hakkında geribildirimde bulunurum." şeklinde ifadeler kullanmışlardır.

Dördüncü tema ile ilgili olarak M3: "Denetim süreci doğrultusunda birebir öğretmenle zayıf yönleri; geliştirmesi 
gereken yönleri hakkında geribildirimde bulunurum.”, M1: "Yapılmasının daha iyi olabileceğini düşünüyorum. Gibi görüşmeler yaptığımız olur.", M2: "Şunlara da dikkat ederseniz daha güzel olur. Başarılısınız bu başınıza daha çok başarı katacaktır... Daha sonra hangi eksiklerinin olduğunu, onları kırmadan üzmeden, kırmadan, soğutmadan meslekten uygun bir dille anlatırım." ve M4: "Öğretmenimle gözlemlerimi paylaşır olumluya teşekkür, olumsuza ise olumlu bir dille rehberlik yaparım." şeklinde ifadeler kullanmışlardır.

Beşinci tema ile ilgili olarak M1: “Eğitim öğretimle ilgili o derste görülen konu ile alakalı izlenen yol ve yöntem, çocuklara söz hakkı tanıma, onlara karşı kullandığı kelimeler, onlarla iletişim kurma dinleme, dinlerken çocukların gözüne bakma, çocukların seviyesine inebilme gibi hassasiyet gösterilmesi gereken konularda düşüncelerimi yine öğretmenime aktarıyorum." ve M5: "Dersi öğrenci merkezli işleyip işlenmediği, öğrencilere yeterince söz hakkı verilip verilmediği, zamanın verimli kullanışı ile ilgili yorumlarımı yaparım." şeklinde konuşmuşlardır.

Altnncı tema ile ilgili olarak M1: "Denetimlerde varsa dikkat çekici ve farklı uygulamalar onları notlarımız arasına alıyoruz.", M2: "Özellikle ben kendim not alırım. Hangi farklı uygulamaları yaptınız hocam? Ne yapıyorsunuz? diye." ve M3: "Öğretmenin derste uyguladığı fark yaratan yöntemleri neleri dikkate alarak uyguladığını, öğrencilere kattğı değeri, öğretmenin fark yaratan uygulamalarını takdir ederek teşvik ederim." demişlerdir.

Yedinci tema ile ilgili olarak M5: "Arkadaşlar benim dikkatimi çeken bir uygulama var. Arkadaşımızın uygulaması şöyledir. Bu çalışa uygulanabilir diye söylüyorum." ve M1: "Öğrencilerle birlikte Konuşarak oluşturdukları yöntem ve teknikler uygulamalar var. Özellikle bunları konuşup ortaya koymaya çalışıyoruz." şeklinde örnekler vermişlerdir.

Sekizinci tema ile ilgili olarak M2: "ilk öğretmenler kurulunda Bunu paylaşırım arkadaşlarla. Onların da yapmasında fayda gördüğümü ve yapabileceklerini söylerim. isteyenlerin hizmetine sunarız.", M3: "Diğer zümre öğretmenleriyle de paylaşılması için desteklerim.", M4: "Hep olumlu örnekler diğer öğretmenlerle paylaşılması önemli, ama her öğretmenin az da olsa olumlu yanı vardır, firsat buldukça hepsini paylaşırım." ve M1: "Öğretmenler kurulu toplantımızın 3 gün sürdü. Arka arkaya kurulumuzu sürdürdük. Buradaki hedefimiz bütün arkadaşlarımızın bu kurulda söz alması. Uygulamalarını anlatması idi... Geçen yıl birinci sınıf okutmuş öğretmenlerimiz birinci sınıf tecrübelerini bu yıl birinci sınıf okutacaklara anlatt." demişlerdir.

Tablo 6. Öğretmenlerin görüşlerine göre gözlem sonrası görüşme sürecinde okul müdürlerinin gerçekleştirdikleri denetsel etkinlikler.

\begin{tabular}{|c|c|c|c|c|c|}
\hline \multirow{2}{*}{ Temalar } & \multicolumn{3}{|c|}{ Devlet Okulu } & \multicolumn{2}{|c|}{ Özel Okul } \\
\hline & Ö1 & Ö2 & Ö4 & Ö3 & Ö 5 \\
\hline Yıllık plan çerçevesinde genel değerlendirme yapma & * & $*$ & & $*$ & \\
\hline Ders sürecinde gözlemlenen özelliklere ilişkin olumlu yönleri vurgulama & * & $*$ & & & $*$ \\
\hline Derse başlama ve dikkat çekme sürecinin değerlendirilmesi & * & $*$ & & & \\
\hline Öğrenci merkezli olumlu ders atmosferi oluşturma & * & $*$ & $*$ & & $*$ \\
\hline Zamanı etkili ve verimli kullanma & * & $*$ & $*$ & & $*$ \\
\hline Beden dili, ses tonu, jest ve mimiklerin etkin kullanımı & * & $*$ & $*$ & * & $*$ \\
\hline Saygı, sevgi, hoşgörüye dayalı iletişim ortamı oluşturulması & & $*$ & & & $*$ \\
\hline Uygulamalarda öğrenme hızı ve algı farklılıklarını dikkate alan firsat ve olanak sunma & & $*$ & $*$ & $*$ & $*$ \\
\hline İstenmeyen davranışlarla başa çıkma & * & $*$ & & & $*$ \\
\hline Derste kullanılan etkinliklerin ve materyallerin değerlendirilmesi & * & $*$ & $*$ & & $*$ \\
\hline Öğrencilerin kişisel gelişim etkinlikleri ve yönlendirme çalışmalarının değerlendirilmesi & * & & & * & $*$ \\
\hline Öğrencileri derse katma ve kendilerini ifade etme olanağının sunulması & $*$ & $*$ & & $*$ & \\
\hline Öğrenilenlerin günlük hayatla ilişkilendirilmesini sağlama ve kazanımların pekiştirilmesi & & & & $*$ & $*$ \\
\hline
\end{tabular}

Tablo 6'da verilen birinci tema ile ilgili olarak Ö1: "Yıllık plana uygun gittiğimizi, müfredata uygun gittiğimizi, plan konusu tek orada gündeme geldi.", Ö2: "Planımı uygun buldu. Müdür bey planımı gayet güzel olduğunu belirten ifadelerde bulundu." ve Ö3: "Ders plan ve program akışı aksamadan ders işlenmiştir." Şeklinde ifadeler kullanmışlardır.

İkinci tema ile ilgili olarak Ö1: “ Dersimin gayet güzel olduğu, yani memnun kaldığını belirtti. İyi intiba içinde kaldığını söyleyerek ayrıldı.", Ö2: "Birinci sınıf öğretmeniyim Benim Okuma yazma konusunda oldukça yeterli olduğumu ifade etti." ve Ö5: "Pozitif yönde bir değerlendirme oldu. Daha da iyiye gideceği hakkında motive etti." demişlerdir." 
Üçüncü tema ile ilgili olarak Ö2: “Oldu tabii ki. Derse beraber girmiştik. Beraber girdikten sonra derse girişim çocukları motive edişim müdür beyin hoşuna gitti." ve Ö1 "Kendisi de etkili olduğunu, dikkat çekmenin önemini vurguladı." demişlerdir.

Dördüncü tema ile ilgili olarak Ö1: "Öğrenci merkezli işlerim. Öğrenciye daha çok aktif rol vermeye çalışan bir öğretmenim." , Ö4: "Dersi öğrenci merkezli işlediğimi söyledim." ve Ö5: "Çoğunlukla öğrenciyi de işin içine sokmak gerektiğini söyledi. Konuyla ilgili çocuklara söz hakkı vermeli, onlardan olumlu dönütler almamı söyledi." demişlerdir.

Beşinci tema ile ilgili olarak Ö1: "Plan ve program içerisinde kaldım. Müdür beye hangi derste olduğumuzu hangi konuyu işleyeceğimizi ve ne zaman biteceğini, Konunun ölçme değerlendirme olduğunu söyledim. O konuda uygun olduğunu söyledi.", Ö2: "Verimli olduğunu söyledi. Zamanı yeterli ve verimli bir şekilde kullandığını söyledi.", Ö4: "Zamanı etkin kullandığımı söyledi.", Ö5: "Konunun anlaşılıp anlaşımamasına göre zamanı etkili bir şekilde kullandığımı söyledi." demişlerdir.

Altıncı Tema ile ilgili olarak Ö1: "Yani ses tonumu ve mimiklerimi fazlaca kullanan bir insanım. Müdür bey yetersiz görseydi söyleyeceğini düşünüyorum.”, Ö3: "Ses tonumu ve mimiklerimi etkili kullandığımı düşünüyorum. Müdürüm bu konuda beni uyarmadı.", Ö4: "Ses tonumu ve mimik hareketlerimi iyi kullandığımı söyledi." ve Ö5: "Ses tonumun daha yüksek olması gerektiği, fakat ders anlatı̧ı ve mimiklerde genel anlamda güzel olduğumu söyledi." demişlerdir.

Yedinci tema ile ilgili olarak Ö1: "Öğrenciler yanlış cevap verse de doğruyu buldurtmaya çalıştım. Bu konuda bir görüşmemiz olmadı.", Ö2: "Ben yanlış cevap veren çocuğa da olumlu davranııım. Teşvik ederim Doğru yolu nasıl buldurabilirim? Yöntemleri kullanarak çocuğa doğruyu buldururum. Onu incitmeden, kırmadan...", Ö2: ". Çocuklar ile ilgili iletişimimiz çok beğendi. Gayet iletişimin güzel olduğunu ifade etti kendisi bana." ve Ö5: "Olumsuz cevapta öğrencinin rencide edilmemesi gerektiği. Öğrencilere karşı tatlı sert olunması gerektiğini söyledi. Kendilerine değer verildiğini hissedebilmeleri için ismiyle hitap etmemi söyledi. Söz hakkı verme ile ilgili konuşuldu." demişlerdir.

Sekizinci tema ile ilgili olarak Ö2: "Hoşuna gitmişti hatta. Geriden gelen öğrencilerim vardı. O Öğrenciler ile ilgili benim ilgimi beğendiğini söyledi. O çocuklarla ayrı ayrı ilgilendiğimi gördü. Önden giden çocuklar ile de yeterince ilgilendiğimi ifade etti. Hani her ikisine de zaman ayırıyorum. Sınıf içerisinde her iki gruba da 40 dakikalık süreye orantlı şekilde ayırdığımı söyledi.", Ö5: "Geç anlayan öğrenciler için onların seviyesine inerek daha sade dil kullanmak gerektiğini söyledi.", Ö3: "Öğrencilere sevgi ve içtenlikle yaklaşımlarım, onlara verdiğim değer, onlara kendilerini ifade etme firsatı tanımam ve cesaretlendirmem müdürüm tarafindan beğenilmiştir. Olumlu düşünceler paylaşılmıştrr." ve Ö4: "Her öğrenciye eşit firsat vermemiz gerektiğini konuştuk" demişlerdir.

Dokuzuncu tema ile ilgili olarak Ö1: "iki üç öğrencimizde farklılık var. Çok hareketli. O çocukları biraz daha ön plana çıkararak uygulamalar yaptığımı söyledim. O da memnun olduğunu söyledi." demiştir.

Onuncu tema ile ilgili olarak Ö1: “Öğrenciye daha çok aktif rol vermeye çalışan bir öğretmenim. O konuda müdür bey bir şey söylemedi." demiştir.

On birinci tema ile ilgili olarak Ö1: "iki tane farklı düzeyde öğrencimiz olduğunu söyledim. Bu öğrencilerle ilgili farklı çalışmalar yaptığımızı söyledim. Önceden de okul müdürü ile bunları paylaşmıştk.", Ö3: "Bol bol kitap okumaları ve hayal güçlerini geliştirici oyun, etkinlik gibi sosyal faaliyetlere katılımını müdürle konuştuk.", ve Ö5: "Onların çabalarını mükâfatlandırılıp, teşvik etmek gerektiği konuşuldu." demişlerdir.

On ikinci tema ile ilgili olarak Ö1: “O esnada soru cevap şeklindeydi dersimiz. Müdür bey de olumlu bulmuştur.", Ö2: "Çocukların çok özgüvenli olduğunu ifade etti. Zaten benim sınıfinda çocuklar serbesttir. Düşündüklerini o anda ifade edebilirler. Bunun da güzel olduğunu ifade etmişti." ve Ö3: "Öğrencilerin derse katılımı önemli olduğu konuşulmuştur." demişlerdir.

On üçüncü tema ile ilgili olarak Ö3: “Özgüveni yüksek, sınıf ve okul kurallarına uyan, çalışkan ve başarılı öğrencilerin okulda öğrendiklerini günlük hayatta kullanmalarına odaklı görüş, düşünce ve beklentileri konuşulur ve diğer öğretmenlerle paylaşılır." ve Ö5: "Öğrendikleri bilgileri atölye ve laboratuvarlarda uygulamaya geçirmeleri ile alakalı zemin hazırlamak gerektiği konuşuldu." demişlerdir.

\section{Okul Müdürlerinin Öğretmenlerin Ders Performanslarını Değerlendirme Yöntemleri}

Bu bölümde okul müdürlerinin öğretmenlerin ders performanslarını değerlendirme yöntemlerine ilişkin müdür ve öğretmen görüşleri tablo 7'de sunulmuştur. 
Tablo 7. Müdürlerin ve öğretmenlerin denetim sonunda performans değerlendirme yöntemine ilişkin görüşleri.

\begin{tabular}{|c|c|c|c|c|c|}
\hline \multirow{2}{*}{ Temalar } & \multicolumn{3}{|c|}{ Devlet Okulu } & \multicolumn{2}{|c|}{ Özel Okul } \\
\hline & M1 & $\mathrm{M} 2$ & M5 & M3 & M4 \\
\hline \multicolumn{6}{|l|}{ Müdürlerin değerlendirme yöntemine ilişkin görüşleri } \\
\hline Öğretmen değerlendirmesinde standart değerlendirme ölçütleri kullanma & $*$ & & $*$ & $*$ & \\
\hline $\begin{array}{l}\text { Bireysel farklılıklar ve dersin kendine özgü yanlarını esas alan durumsal değerlendirme ölçütleri } \\
\text { geliştirme }\end{array}$ & & $*$ & & & $*$ \\
\hline Öğretmenlerin değerlendirme yöntemine ilişkin görüşleri & Ö1 & Ö2 & Ö4 & Ö3 & Ö 5 \\
\hline Öğretmen değerlendirmesinde standart değerlendirme ölçütleri kullanma & $*$ & $*$ & $*$ & $*$ & \\
\hline $\begin{array}{l}\text { Bireysel farklılıklar ve dersin kendine özgü yanlarını esas alan durumsal değerlendirme öl- } \\
\text { çütleri geliştirme }\end{array}$ & & & & & $*$ \\
\hline
\end{tabular}

Tablo 7'de verilen değerlendirme ölçütlerine ilişkin M3: “incelemelerimi yapttğım plan üzerinden bireysel değerlendirme yapıyoruz... Ders gözlemi yapılacak öğretmen için kurum tarafindan hazırlanan matbu formu ve değerlendirme ölçeğini yanımda götürüyorum.", M1: "Zaten kullandığım ve çeşitli kaynaklardan Bakıp kendince geliştirdiğim ve not almak üzere hazırladığım Bir form var.", M5: “"Taslak form hazırlarım. Bütün sınıf değerlendirmelerimde bunu kullanıyorum.", M2: "'Önceden mutlaka bir hazırlığım olur." M3: "Ders gözlemi yapılacak öğretmen için kurum tarafindan hazırlanan matbu formu ve değerlendirme ölçeğini yanımda götürüyorum.", M4: "Her an ölçme değerlendirme kriterlerine yönelik ilgili alana ve öğretmene yönelik program içeriğinin sürecini öğrenir hazırlık yaparım." şeklinde ifade etmişlerdir.

Tablo 8 de verilen değerlendirme ölçütlerine ilişkin öğretmenlerden Ö2: "Bize liste verdi. hangi konuda... hangi kriterlerin göz önünde bulundurulacağı ile ilgili liste vermişti.", Ö3: "(Gözlem öncesi görüşmede) Değerlendirme kriterleri üzerinde konuşuldu. (Denetim sonrasında) Denetim kriterlerine uygun...kanaatini belirtmiştir.", Ö1: "O konuda müdür bey ile pek konuşmamız olmadı." (Değerlendirme müdür tarafindan yapılmıştır.) ve Ö4: "'Konuşmadık." (Değerlendirme müdür tarafindan yapılmıştr.) demişlerdir. Ö5: ise "Sınıf hakimiyeti, konuya hakim olmak, zamanın verimli kullanılması, öğrencilerle etkili iletişim konusunda konuştuk." şeklinde bir değerlendirme yapıldığından söz etmiştir.

\section{Okul Müdürlerinin Görüşlerine Göre Denetsel Yeterlik Kazanma Yöntemleri}

Okul müdürlerinin görüşlerine göre kendilerinin denetsel yeterlik kazanma yöntemlerine ilişkin görüşleri tablo 8'de sunulmuştur.

Tablo 8. Okul müdürlerinin denetsel yeterliklerini kazanma yöntemine ilişkin görüşleri.

\begin{tabular}{|c|c|c|c|c|c|}
\hline \multirow{2}{*}{ Alt temalar } & \multicolumn{3}{|c|}{ Devlet Okulu } & \multicolumn{2}{|c|}{ Özel Okul } \\
\hline & M1 & $\mathrm{M} 2$ & M5 & M3 & M4 \\
\hline Mevzuat takibi ve kişisel deneyimlerle öğrenme & $*$ & $*$ & $*$ & & $*$ \\
\hline Meslektaşlardan yararlanma & $*$ & & $*$ & & $*$ \\
\hline Eğitim yoluyla öğrenme & & & & * & $*$ \\
\hline Müfettişlerden öğrenme & $*$ & & $*$ & & $*$ \\
\hline
\end{tabular}

Tablo 8'de verilen temalarda görüldüğü gibi ders denetimi yapma yeterliklerini kazanma yöntemleri konusundaki ifadeleri şöyledir. "Tecrübe işi, herhangi bir yazılı yani basılı kaynaktan bunu öğrenmek çok zor. M2", "Genel Merkezde alınan yönetici eğitimlerinde öğrendim. M3", "Bu alanda eğitim aldım ve müfettişlik yaptım. M4", "Başka okul müdürlerinin yani idarecilerin yapmış olduğu, Internet ortamına düşen bu çalışmaların hepsini harmanlayıp ders denetimlerini yapıyorlar. Okul müdürleri aşağı yukarı aynı konularda hassasiyet göstererek ders denetimlerini yapıyorlar. Özellikle Maarif müfettişlerinden faydalanıyorum. Onların daha da yoğunlaştıkları alanlar bunlar ve onların geliştirdikleri formlar var. M1", "Yönetmelikler, okul müdürleri maarif müfettişlerinden faydalandım. M5" demişlerdir.

\section{Sonuçlar ve Öneriler}

Çalışmada okul müdürleri tarafindan gerçekleştirilen ders denetimi etkinlikleri rehberlik etkililiği açısından incelenmiştir. Bu bölümde ilk olarak okul müdürlerinin denetim ve rehberlik yeterliklerini kazanma sürecine ilişkin sonuçlar, 
ikinci olarak ders denetim sürecine ilişkin sonuçlar (gözlem öncesi görüşme, gözlem aşaması ve gözlem sonrası görüşme) üçüncü olarak okul müdürlerinin öğretmenlerin ders performanslarını değerlendirme yöntemlerine ilişkin sonuçlar sunulmuş ve önerilere yer verilmiştir.

Gözlem öncesi görüşme boyutunda 1) hem özel hem de devlet okullarında görev yapan okul müdürleri denetimin gerçekleştirileceği ders öncesi öğretmenlere haber verdiklerini ve gözlem öncesi görüşme yapmaya önem verdiklerini belirtmişlerdir. Yeşil ve Ali (2015) de müdürlerin denetim yapacaklarını ders denetimi yapmadan önce öğretmenlere haber verdiklerini belirlemişlerdir. 2) Okul müdürlerinin gözlem öncesinde dersin konusu, kullanılacak yöntemler ve teknikler hakkında değerlendirme yapma, etkinlikler ve materyaller ile kazanım ölçme ve değerlendirme etkinlikleri hakkında konuşma firsat ve olanağı buldukları anlaşılmaktadır. 3) Devlet okullarında ağırlıklı olmak üzere öğretmenler kurulu toplantılarının da denetleme ve değerlendirme faaliyetlerinin irdelenmesi için bir firsat olarak değerlendirildiği görülmektedir. 4) Öğretmenlerin görüşleri, hem özel hem de devlet okullarında gerçekleştirilen gözlem öncesi görüşmelerin planlı olarak gerçekleştirildiğini ortaya koymaktadır. Öğretmenler bu sürecin sınıfin genel durumu, ders içi ve ders dışı etkinlikler, program, zümre kararları, ders araç-gereçleri, derste kullanılan teknolojiler ve ders işleme yöntemleri, öğrencilerin öğrenme güçlükleri ve bireysel farklılıkları, istenmeyen davranışlar ve başa çıkma yöntemleri gibi konularda bütünsel bir hazırlık içerdiği görüşündedir. Bu bulguların aksine Özbaş (2002) öğretmenlerin sınıf denetimi ile ilgili hazırlıkların hiç yapılmadığına inandıklarını; müdürlerin ise az yapıldığı görüşünde olduklarını belirlemiştir.

Ders gözlemi boyutunda 1) hem özel hem de devlet okullarında, okul müdürlerinin, fiziki durum, öğretim yöntemleri ve teknolojileri, sınıf kuralları, program içeriği, dersin işlenmesi, konular arası geçiş ve ilişkilendirme ders araç-gereçlerinin kullanımı, hijyen ve kişisel bakım, bireysel farklılıklar, duygular, motivasyon, öğrenci merkezli öğretim uygulamaları, zaman yönetimi, etkili iletişim süreci, araştırma ve yaratıcılığa özendirme açısından ödevlendirme ve ölçme ve değerlendirme etkinliklerini inceleme ve değerlendirme konusu yaptıkları görülmektedir. 2) Öğretmenler de okul müdürlerinin sınıfın fiziki koşullarını, etkinlik ve materyal destekli öğrenci merkezli öğretim uygulamalarını, kullandıkları yöntem ve teknikleri, zaman yönetimi, kazanımların gerçekleştirilmesini, bireysel farklılıkları, ödev uygulamalarını değerlendirdiklerini belirtmişlerdir. Okul müdürlerinin gözlem sürecinde inceleme konusu yaptkları durumların öğretmenlerin belirttiklerinden daha çeşitli olması dikkat çekicidir. Yeşil ve Ali (2015) ders gözlem aşamasında müdürlerin önem verdikleri konuların evrak, öğrencilerin derse katılımı, sınıf yönetimi, sınıfin fiziki durumu, kılık kıyafet, öğretmenin müdüre karşı tutumu ve dersin sunumu olduğunu bulmuştur. Buna karşılık Özbaş (2002) müdürlerin sınıfin fiziksel düzeni, plan program ve öğretim etkinliklerini orta düzeyde denetlendiklerine inandıklarını belirlemiştir. Bu konuda öğretmenlerin ise olumsuz görüşte oldukları vurgulanmıştr.

Gözlem sonrası görüşme boyutunda 1) okul müdürlerinin öğretmenlerle uygun zamanın planlanması, eğitim öğretim, yılı başında yapılan planlamaların gözden geçirilmesi, ders uygulamalarına iliş̧in güçlü ve zayıf yanların vurgulanması, yöntemlerin, tekniklerin, kullanılan etkinliklerin ve materyallerin gözden geçirilmesi, farklı uygulamaların değerlendirilmesi, eksikliklerin giderilmesine yönelik farklı uygulamaların tartş̧ıması, yaratıı-iyi örneklerin değerlendirilmesi çerçevesinde değerlendirmeler yaptkları anlaşılmaktadır. 2) Öğretmenlerin gözlem sonrası görüşmeye yönelik görüşleri daha ayrıntılı bir değerlendirme yapıldığına işaret etmektedir. Bu çerçevede elde edilen bulgular, derse başlama ve dikkat çekme, ders süresince karşııklı sevgi ve saygı esasına dayalı etkili bir iletişim ortamı oluşturma, bireysel farklııkları esas alan öğrenci merkezli bir öğretim süreci, katılımı sağlama, öğrenme konularının günlük hayatla ilişkilendirilmesi ve kazanımların pekiştirilmesi, öğrencilerin kişisel gelişimlerinin sağlanması ve yönlendirme, davranış yönetimi, etkinlik ve materyal kullanımı, zamanı etkili ve verimli kullanma ve olumlu yönleri vurgulayan genel değerlendirme çerçevesinde kapsamlı bir görüşme ve değerlendirme süreci bulunduğunu ortaya koymaktadır.

Müdürlerin ve öğretmenlerin denetim sonunda performans değerlendirme yöntemine ilişkin görüşleri ağırlıklı olarak standart bir değerlendirme formu ve içeriği etrafinda şekillendiğini ortaya koymaktadır. Göreli olarak müdürler bireysel farklılıkları ve dersin kendine özgü yanlarını esas alan durumsal değerlendirme ölçütleri geliştirme eğilimi yansıtmışlardır. Bu konuda hem bir devlet okulu hem de bir özel okul müdürünün görüş bildirmiş olması standart değerlendirme yaklaşımını sorgulama ve farklı arayışları yansıtma bakımından anlamlıdır. Bununla birlikte bireysel farklıık ve duruma özgülük temelinde değerlendirmenin yalnızca bir özel okul öğretmeni tarafindan dile getirilmiş olması standartlar çerçevesinde bir denetim ve değerlendirme uygulamasının güçlü bir şekilde devam ettiğine işaret etmektedir. Okul müdürlerinin standartlara dayalı değerlendirme yaklaşımında olması çeşitli çalışmalarda da olumsuz sonuçları ile tartş̧ımıştr. Örneğin bu yaklaşım çerçevesinde yapılan okul müdürü tarafindan sicil notu verilmesi şeklindeki bir uygulamanın denetlenen üzerinde olumsuz etkiler yaratabileceği vurgulanmıştır (Balcı, Aydın, Yılmaz, Memduhoğlu ve Apaydın, 2007; Başol ve Kaya, 2009; Memduhoğlu ve Taymur, 2010; Uçar, 2012). Okul müdürlerinin değerlendirme konusunda eğitilmeleri gerektiğine yönelik araştırma sonuçları bulunmaktadır (Başol ve Kaya, 2009).

| Kastamonu Eğitim Dergisi, 27(5), 2019 | 
Okul müdürlerinin ders denetimi ile ilgili yeterlik kazanma konusunda daha çok kendi kişisel mesleki tecrübelerinden ve mevzuatta verilen bilgilerden yararlandıkları; yeterli olmadıklarını düşündükleri konularda ise müfettişlere ve meslektaşlara danışma yoluyla kendilerini geliştirmeye çalıştıkları anlaşılmaktadır. Eğitim yoluyla denetim ve rehberlik yeterliği kazanma yalnızca özel okul yöneticileri tarafindan ifade edilmiştir. Bu konuda yapılan çalışmalarda bütünde okul müdürlerinin ders denetiminde kendilerine ilişkin algıların olumlu olduğu, öğretmenlerin ise müdürlerin yeterliklerini düşük düzeyde algıladıkları vurgulanmıştır (Altun, vd., 2015; Bayraktutan, 2011; Demirtaş ve Akarsu, 2016; Yıldız, Akbaşı ve Üredi, 2015a; 2015b; Tonbul, 2017). Okul müdürlerinin denetim ve rehberlik rolleri ile ilgili olarak bilgi, beceri ve koşullar boyutlarında hem erkek hem de kadın öğretmenlerin kararsız düzeyinde fikir belirttikleri; yaşı ve deneyimi fazla olan ve sınıf öğretmenlerinin okul müdürlerinin denetimini yeterince etkili bulamadıkları; 20 yıl ve üzerinde hizmeti bulunan grubun diğer daha az hizmeti bulunan gruplara göre ve sınıf öğretmenlerinin branş öğretmenlerine göre okul müdürlerinin etkililiğini daha düşük düzeyde buldukları belirlenmiştir (Özmen ve Batmaz, 2004; 2006) Karabay (2014) erkek öğretmenlerin kadın öğretmenlere göre yöneticilerin ders denetimini daha etkili bir şekilde gerçekleştirdiklerine ilişkin görüş belirttiklerini ifade etmiştir. Müfettişlerin görüşleri ise etik, tarafsızlık, eğitim durumu, disiplin ve ciddiyet, informal ilişki iklimi, alan uzmanlığı, denetim uzmanlığı, rehberlik, sendika vb. farklı resmi ilişkiler, performans değerlendirmesinde karşılıklı rollerin bulunması gibi çeşitli açılardan müdürlerin ders denetimi yapmasının sorunlu olduğu yönündedir (Altun vd., 2015).

Bütünde değerlendirildiğinde okul müdürlerinin denetleme ve rehberlik ihtiyacını karşılamada başvurulabilecek, amaca uygun bir altyapıya ve pozisyona sahip en önemli adaylar arasında oldukları söylenebilir (Can ve Gündüz, 2016). Bulgulara göre okul müdürlerinin gözlem öncesi görüşme aşamasında, gözlem ve gözlem sonrası görüşmelerde kapsamlı bir denetim anlayışı yansıttkkları söylenebilir. Gerek alan araştırmalarında ortaya konulan bulgular gerekse bu araştrrmada gözlem öncesi görüşme, gözlem ve gözlem sonrası görüşme süreçleri ile ilgili elde edilen bulgular, bu sürecin geliştirilmesine yönelik gerçekleştirilecek girişimlerle daha da olumlu bir süreç ve sonuçlar elde edilebileceğine işaret etmektedir. Bununla birlikte okul müdürlerinin başvurdukları düzey belirleyici değerlendirmenin ise elde ettikleri kapsamlı verilerin değerlendirilmesinde yeterli olmadığı; bireysel farklılıkları esas alan farklı değerlendirme yöntemlerine intiyaç olduğu söylenebilir. Ayrıca yapılan denetimlerde üzerinde durulan kapsamlı konuların niteliksel açıdan durumunu belirlemeye yönelik çalışmalara intiyaç vardır. Okul müdürleri, denetleme ve rehberlik konularında tüm süreçlerde intiyaç duyacakları bilgi ve becerileri kazandırmaya yönelik, süreklilik temelinde, teorik ve uygulamalı eğitimlerle desteklenmelidir. Denetim modeli olarak okul müdürünü merkeze alan bir yaklaşımda, modelin başarılı olabilmesi için okul müdürlerinin üstlendikleri görev ve sorumlulukların, öğretim ve program liderliği odaklı olarak yeniden yapılandırılması gerektiği söylenebilir.

\section{Kaynakça}

Akcan, E. ve Polat, S. (2015). Müfettiş denetiminin öğretmenlerin motivasyonuna etkisi. Uluslararası Sosyal Araştirmalar Dergisi, 8(40), 502-510.

Aküzüm, C ve Özmen (2013). Eğitim denetmenlerinin rollerini Gerçekleştirme yeterlikleri: Bir meta-sentez çalışması. Ekev Akademi Dergisi, 56, 97-120.

Altun, B. (2014). Denetime eleştirel yaklaşım: öğretmen denetimi nasıl olmalı? Yayımlanmamış Yüksek Lisans Tezi, Sosyal Bilimler Enstitüsü Müdürlüğü, Adnan Menderes Üniversitesi, Aydın.

Altun, M., Şanlı, Ö., ve Tan, Ç. (2015). Maarif müfettişlerin, okul müdürlerinin denetmenlik görevleri hakkındaki görüşlerinin incelenmesi. Turkish Studies, 10(3), 79-96.

Aslanargun, E. ve Göksoy, S. (2013). Öğretmen denetimini kim yapmalıdır? Uşak Üniversitesi Sosyal Bilimler Dergisi, 14, 98-121.

Aslanargun, E. ve Tarku, E. (2014) Öğretmenlerin Mesleki Denetim ve Rehberlik Konusunda Müfettişlerden Beklentileri. Kuram ve Uygulamada Eğitim Yönetimi, 20(3), 281-306.

Aydın, M. (2014). Eğitim yönetimi (10 Baskı). Ankara: Gazi Kitabevi.

Aydın, i. (2016). Öğretimde denetim. Pegem Atf Indeksi, 6, 1-280.

Babaoğlan, E. (2016). Kadın ve erkek eğitim denetmenlerinin kişisel ve mesleki özellikleri. Mersin Üniversitesi Eğitim Fakültesi Dergisi, 12(2), 757-769.

Balcı, A. Aydın, İ. Yılmaz, K. Memduhoğlu, H. B. Apaydın, Ç. (2007). Türk eğitim sisteminde ilköğretimin yönetimi ve denetimi: mevcut durum ve yeni perspektifler. Türkiye'de Okul Öncesi Eğitim ve Ilköğretim Sistemi: Temel Sorunlar ve Çözüm Önerileri (Edt: S. Özdemir, H. Bacanlı ve M. Sözer), Ankara: Türk Eğitim Derneği, 126-185.

Başar, H. (2000). Eğitim denetçisi. Ankara: Pegem A Yayıncılık.

Başol, G. ve Kaya, I. (2009, 1-3 Mayıs). The primary teachers' opinions on their performance evaluation by school administrators. Paper Presented at The First International Congress of Educational Research, Online Full Text Book, Retrieved from http:// 
oc.eab.org.tr/egtconf/pdfkitap/pdf/545.pdf, Çanakkale, Turkey: Çanakkale 18 Mart University.

Bayraktutan, İ. (2011). Okul müdürlerinin denetim rolleri (Sivas ili örneği). Yayımlanmamış Yüksek Lisans Tezi, Sosyal Bilimler Enstitüsü Eğitim Bilimleri Anabilim Dalı/ Eğitim Yönetimi, Teftişi, Planlaması ve Ekonomisi Bilim Dalı İlköğretim Cumhuriyet Üniversitesi, Sivas.

Bitan, K., Haep, A. \& Steins, G. (2015). School inspections still in dispute - an exploratory study of school principals' perceptions of school inspections. Int. J. Leadershıp in Education, 18(4), 418-439.

Bursalıŏlu, Z. (2002). Okul yönetiminde yeni yapı ve davranış (12. Baskı). Ankara: PegemA Yayıncılık.

Can, E. ve Gündüz, Y. (2016). İlkokullarda çalışan öğretmenlerin, maarif müfettişleri ve okul müdürlerinin yapmış olduğu rehberlik çalışmalarından yararlanma düzeylerinin incelenmesi. Kuram ve Uygulamada Eğitim Yönetimi Dergisi, 22(1), 1-28.

Ceylan, M ve Ağaoğlu, E (2010). Eğitim denetçilerinin danışmanlık rolü ve danışmanlık Modelleri. Elementary Education Online, 9(2), 541-551.

Creswell, John W. (2014): Research design. Qualitataive, quantiative and mixed methods approahes (4th. Ed). Lincoln: Sage Publications.

Çağlar, Ç. (2014). Sınıf yönetimini etkileyen etmenler. İçinde, M. Çelikten ve M.Teyfur (Ed.) Yapılandırmacı yaklaşıma göre sınıf yönetimi (3. Baskı, ss.169-184). Ankara: Anı Yayıncılık.

Demirtaş, Z ve Kahveci, G. (2015). Öğretmen adaylarının denetim, denetmen ve denetlenen kavramlarına ilişkin metaforik algıları. Eğitim ve Insani Bilimler Dergisi: Teori ve Uygulama, 6(11), 23-58.

Demirtaş, H. ve Akarsu, M. (2016). Öğretmen teftişini müfettiş yerine okul müdürünün yapmasına ilişkin öğretmen görüşleri. İnönü Üniversitesi Eğitim Fakültesi Dergisi, 17(2), 69-93.

Devlet Memurları Kanunu, (1965). Resmî Gazete. Yayım Sayı: 12056, Tarih. 23/7/1965 http://www.mevzuat.gov.tr/MevzuatMetin/1.5.657.pdf. Erişim Tarihi:15.11.2018.

Erdem, A. R. ve Eroğul, M. G. (2012) Sınıf öğretmenlerinin görüşlerine göre ders denetiminde eğitim müfettişlerinin öğretmene ilişkin tutumları. Pamukkale Üniversitesi Eğitim Fakültesi Dergisi, 31, 13-26.

Glikman, C. D., Gordon, S.P ve Ross-Gordon, J. M. (2014). Denetim ve öğretimsel liderlik: Gelişimsel bir yaklaşım. (Çev. Edt. M. B. Aksu ve E. Ağaoğlu). Ankara: Anı Yayıncılık.

Karabay, H. (2014). Okul yöneticilerinin ders denetimleri yönüyle branş öğretmenlerinin mesleki gelişimlerine katkıları. Yayımlanmamış yüksek lisans tezi, Eğitim Bilimleri Enstitüsü Eğitim Yönetimi ve Denetimi Ana Bilim Dalı, Yeditepe Üniversitesi, İstanbul.

Karakuş, M. ve Yasan, T. (2013). Denetmen ve öğretmen algılarına göre il eğitim denetmenlerinin yeterlikleri. Dicle Üniversitesi Ziya Gökalp Eğitim Fakültesi Dergisi, 21, 1-19.

Kayıkçı, K. (2005). Milli Eğitim Bakanlığı müfettişlerinin denetim sisteminin yapısal sorunlarına ilişkin algıları ve iş doyum düzeyleri. Kuram ve Uygulamada Eğitim Yönetimi, 44, 507-527.

Kayıkçı, K. ve Şarlak, S. (2013). İlköğretim okullarında denetimin etkili işleyişini zorlaştıran örgütsel engeller. Elementary Education Online, 12(2), 461-478.

Kayıkçı, K., Cantürk, G. ve Yılmaz, O. (2014) Okul müdürlerinin kliniksel denetime ilişkin genel algı ve değerlendirmeleri. Kuram ve Uygulamada Eğitim Yönetimi, 20(2), 217-249.

Kayıkçı, K. (2016).Eğitimde Denetim sisteminin yasal dayanakları, örgüt ve yönetim yapısı, maarif müfettişlerinin seçilmesi ve yetiştirilmesi. İçinde ,M. Sağır ve S. Göksoy (Ed), Eğitimde denetim ve değerlendirme (1. Baskı, ss. 91-148). Ankara: Pegem Akademi.

Kocabaş İ. ve Yirci R. (2011, 22-24 Haziran). Denetmen algılarına göre denetimde yaşanan sorunlar. 3. Uluslararası Eğitim denetimi Kongresi, Bildiri Kitabı, Ankara: Tüm Eğitimciler ve Eğitim Müfettişleri Sendikası Yayını.

MEB. (1973). Milli eğitim temel kanunu. Resmi Gazete. Yayım Sayı: 14574, Tarihi: 24/6/1973.

MEB. (2011). 652 Sayılı Millî Eğitim Bakanlığının teşkilat ve görevleri hakkında kanun hükmünde kararname. Resmi Gazete. Tarih:14/09/2011, Sayı:28054.

MEB. (2013). Millî Eğitim Bakanlığı ortaöğretim kurumları yönetmeliği. Resmi Gazete. Sayı: 28758, Tarih: 07/09/2013.

MEB. (2014). 6528 Sayılı Millî Eğitim Temel Kanunu ile bazı kanun ve kanun hükmünde kararnamelerde değişiklik yapılmasına dair kanun. Resmi Gazete. Tarih:14/03/2014, Sayı:28941.

MEB. (2014a). Millî Eğitim Bakanlığı okul öncesi eğitim ve ilköğretim kurumları yönetmeliği. Resmi Gazete. Tarih: 26/07/ 2014, Sayı: 29072.

MEB. (2016a). Millî Eğitim Bakanlığının teşkilat ve görevleri hakkında kanun hükmünde kararname ile bazı kanun ve kanun hükmünde kararnamelerde değişiklik yapılmasına dair kanun. Resmi Gazete. Sayı 29913, Kanun No: 6764.

MEB. (2016b) ilkokul/ortaokul rehberlik ve denetim rehberi. Milli Eğitim Bakanlığı Rehberlik ve Denetim Başkanlığı, Ankara.

MEB. (2016c) Lise ve dengi okullar rehberlik ve denetim rehberi. Milli Eğitim Bakanlığı Rehberlik ve Denetim Başkanlığı, Ankara.

MEB. (2016d) Özel eğitim kurumları rehberlik ve denetim rehberi. Milli Eğitim Bakanlığı Rehberlik ve Denetim Başkanlığı, Ankara.

| Kastamonu Eğitim Dergisi, 27(5), 2019| 
MEB. (2016e). Okulöncesi eğitim kurumları rehberlik ve denetim rehberi. Milli Eğitim Bakanlığı Rehberlik ve Denetim Başkanlığı, Ankara.

Memduhoğlu, H. B. (2012). Öğretmen, yönetici, denetmen ve öğretim üyelerinin görüşlerine göre Türkiye'de eğitim denetimi sorunsalı. Kuram ve Uygulamada Eğitim Bilimleri, 12(1), 135-156.

Memduhoğlu, H. B. ve Taymur, A. (2010). Türkiye'de Eğitim Denetiminin Yeniden Yapılanmasına iliş̧kin Bir Model Önerisi. Uluslararası Katılımlı Ulusal Eğitim Denetimi Sempozyumu. Tüm Eğitimciler ve Müfettişler Sendikası (TEM-SEN), Ankara (22-23 Haziran 2009), 146-165.

Memduhoğlu, H. B. ve Taymur, A. (2016). Türkiye'de eğitim denetimi alt sisteminin yeniden yapılandırılmasına ilişkin bir model önerisi. Pegem Eğitim ve Öğretim Dergisi, 4(2), 2014, 25-44.

Oğuz, E., Yılmaz, K. ve Taşdan, M. (2007). İlköğretim denetmenlerinin ve ilköğretim okulu yöneticilerinin denetim inançları. Sosyal Bilimler Dergisi, 17, 39-51.

Okutan, M. (2016). Eğitim yönetimi ve denetiminde örnek olaylar. Pegem Atff Indeksi, 2, 1-248.

Özan, M. B ve Özdemir, T.Y (2010, 23-25 Haziran). Denetimin öğretmen üzerinde oluşturduğu psikolojik baskı, K, Turgut, Y. Kürşad ve A. Yahya, (Ed). II. Uluslararası Katlımlı Eğitim Denetimi Kongresi Bildiriler Kitabı, Kütahya: Dumlupınar Üniversitesi : TEM-SEN.

Özbaş, M. (2002). İlköğretim okulu müdürlerinin sınıf içi etkinliklerin denetimde yapmaları gereken ve yapmakta oldukları işler konusunda müdür ve öğretmen görüşleri. Yayımlanmamış Yüksek Lisans Tezi, Sosyal Bilimler Enstitüsü Eğitim Yönetimi Teftişi Planlaması ve Ekonomisi Hacettepe Üniversitesi, Ankara.

Özmen, F. ve Batmaz, C. (2004). İlköğretim okul müdürlerinin öğretmen denetimindeki etkililikleri-cinsiyet ve yaş değişkenine göre öğretmen görüşleri. XIII. Ulusal Eğitim Bilimleri Kurultayı, Malatya: İnönü Üniversitesi, Eğitim Fakültesi.

Özmen, F. ve Batmaz, C. (2006). İlköğretim okul müdürlerinin öğretmen denetimindeki etkililikleri-hizmet yılı ve görev türü değişkenine göre öğretmen görüşleri. Sosyal Bilimler Araşttrmaları Dergisi, 2, 102-120.

Patton, M., Q. (1990). Qualitative evaluation and research (2nd ed.). California: Sage Publications.

Rubin, H. ve Rubin, I. (1995). Qualitative interviewing: The art of hearing data. Sage Publications, CA: Thousand Oaks.

Sabancı, A. ve Sahin, A. (2007). Denetmenlerin, öğretmenlik yeterlik alanları açısından devlet ilköğretim okulu sınıf öğretmenlerine rehberlik görevlerini gerçekleştirme düzeyleri. Eğitim ve Bilim, 32(145), 85-95.

Sabancı, A. ve Yücel, E. (2014). Öğretmenlerin görüşlerine göre denetmenlerin etik dışı davranma düzeyleri. e-International Journal of Educational Research, 5(2), 1-19.

Sağlam, A. Ç. ve Demir, M. (2015). Maarif müfettişlerinin sınıf öğretmenlerine mesleki rehberlik yapma düzeyleri ile öğretmen motivasyonu arasındaki ilişki. International Journal of Human Sciences, 12(2), 1503-1521.

Şahin, S., Çek, F. ve Zeytin, N. (2011). Eğitim müfettişlerinin mesleki memnuniyet ve memnuniyetsizlikleri. Eğitim Yönetimi, 17(2), 221-246.

Tanrı̈ğen, H. (1997). Öğretimin denetimine yönelik bir model: Yönlendirilmiş yoğun denetim. Kuram ve Uygulamada Eğitim Yönetimi Dergisi, 3(3),111-121.

Taymaz, H. (1995). Teftişte karşılaşılan sorunlar ve öneriler. Eğitim Yönetimi, 1, 1.

Tok, T. N. ve Demir, M. (2016). Lisansüstü öğrenci görüşlerine göre eğitim denetimi. Trakya Üniversitesi Eğitim Fakültesi Dergisi, 6(2), 102-125.

Tonbul, Y. (2017). Ders denetimi ile ilgili yönetmelik değişikliğinin maarif müfettişlerinin, okul yöneticilerinin ve öğretmenlerin görüşleri açısından değerlendirilmesi. İlköğretim Online, 16(1), 299-311.

Topçu, í. (2010). Devlet ve özel ilköğretim okullarında yöneticilerin öğretimin denetimi görevlerini yerine getirme biçimleri. Cumhuriyet Üniversitesi Edebiyat Fakültesi Sosyal Bilimler Dergisi, 34(2), 31-39.

Toytok, E. H, ve Çılgın, M. (2015). Eğitim sisteminde yeni yapılan düzenlemede müfettişlerin ve okul müdürlerinin yapttkları denetimin öğretmen algılarına göre incelenmesi (Van ili Edremit ilçesi örneği), 10. Ulusal Eğitim Yönetimi Kongresi Bildiri Kitabı, (1. Baskı, ss.294-296). Ankara: Pegem akademi. İndirilme tarihi:15.04.2017. http://www.eyed-der.org/images/dosya20150513200928.pdf

Uçar, R. (2012). illköğretim okullarında görev yapan öğretmenlerin sınıflarındaki denetim uygulamalarına ilişkin görüşleri. Adnan Menderes Üniversitesi Eğitim Fakültesi Eğitim Bilimleri Dergisi, 3(2), 82-96.

Uğurlu, C. T. ve Usta, H. G. (2016). Eğitimde Denetim tutum ölçeği geçerlik ve güvenirlik çalışması. Journal of Education Faculty, 18(1), 137-159.

Yeşil, D. ve Kış, A. (2015). Okul müdürlerinin ders denetimi. İnönü Üniversitesi Eğitim Bilimleri Enstitüsü Dergisi, 2(3), 27-45.

Yılmaz, K. (2009). Okul müdürlerinin denetim görevi. İnönü Üniversitesi Eğitim Fakültesi Dergisi, 10(1), 19-35.

Yıldırım, A. ve Şimşek, H. (2013). Sosyal bilimlerde nitel araştırma yöntemleri (9. Baskı). Ankara: Seçkin Yayıncılık.

Yıldırım, M. K, (2013). İlköğretim okullarında görev yapan öğretmenlerin, müdürlerin denetim görevini gerçekleştirmelerine ilişkin algılarının örgütsel bağlılıklarına etkisi (Elazığ örneği). Yayımlanmamış Yüksek Lisans Tezi, Eğitim Bilimleri Enstitüsü Eğitim Yönetimi, Teftişi, Planlaması ve Ekonomisi Anabilim Dalı, Fırat Üniversitesi, Elazığ. 
Yıldız, B. Akbaşlı, S. ve Üredi, L. (2015a, 20-22 Mayıs). Kurum müdürlerinin yaptığı rehberlik ve denetim uygulamalarına ilişkin öğretmen görüşlerinin değerlendirilmesi. VII. Uluslararası Eğitim Denetimi Kongresi, İzmir.

Yıldız, B. Akbaşlı, S. ve Üredi, L. (2015b, 20-22 Mayıs). Maarif müfettişlerinin sınıflarda uyguladığı rehberlik ve denetim uygulamaIarının kaldırılmasına ilişkin öğretmen görüşleri. VII. Uluslararası Eğitim Denetimi Kongresi, İzmir. 